US Army Corps of Engineers ${ }_{\circledast}$

Engineer Research and

Development Center
INNOVATIVE SOLUTIONS for a safer, better world

Aquatic Plant Control Research Program

\title{
Establishing Research and Management Priorities for Invasive Water Primroses (Ludwigia spp.)
}

Brenda J. Grewell, Michael D. Netherland, and Meghan J. Skaer Thomason

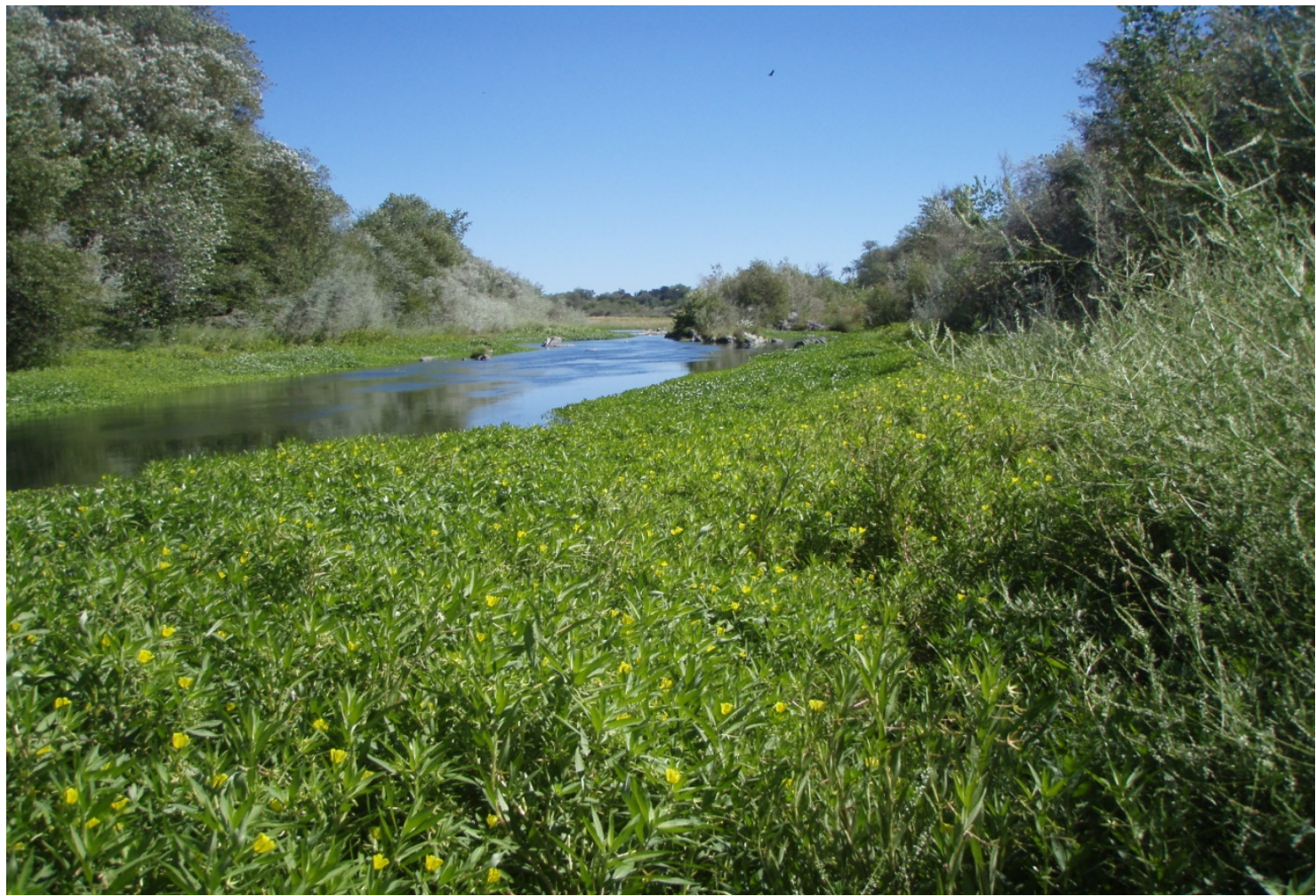


The U.S. Army Engineer Research and Development Center (ERDC) solves the nation's toughest engineering and environmental challenges. ERDC develops innovative solutions in civil and military engineering, geospatial sciences, water resources, and environmental sciences for the Army, the Department of Defense, civilian agencies, and our nation's public good. Find out more at www.erdc.usace.army.mil.

To search for other technical reports published by ERDC, visit the ERDC online library at http://acwc.sdp.sirsi.net/client/default. 


\section{Establishing Research and Management Priorities for Invasive Water Primroses (Ludwigia spp.)}

Brenda J. Grewell and Meghan J. Skaer Thomason

USDA - Agricultural Research Service

University of California - Davis

Department of Plant Sciences MS-4

One Shields Avenue

Davis, CA 95616

Michael D. Netherland

Environmental Laboratory

U.S. Army Engineer Research and Development Center

3909 Halls Ferry Road

Vicksburg, MS 39180-6199

Final report

Approved for public release; distribution is unlimited. 


\section{Abstract}

Creeping water primroses and water primrose-willows are among the most aggressive aquatic invasive plant invaders in the world. These aquatic Ludwigia species can impart severe ecological, economic, and human health impacts in aquatic ecosystems and threaten critical ecosystem functions. The authors expect these impacts to increase with greater global trade and projected climate change. This technical report presents an overview of the biology and ecology of these invasive plant species, along with select management case studies and research efforts. While the need for management approaches has become an important topic, little is known about the distribution of Ludwigia species and how they respond to varying environmental conditions in the U.S. Life history strategies and responses to environmental conditions vary among water primrose species. Therefore, species-specific management approaches may be required, and prevention and control strategies should be customized to the specific phase of the local invasion. This information is important for predicting further spread. Likewise, it is the foundation for risk assessments and effective management. This technical report proposes research priorities to improve understanding of the complexity of the biology and ecological invasion process of water primroses, and it provides resource managers with substantive recommendations for how to prevent and prioritize management of these aquatic weeds.

DISCLAIMER: The contents of this report are not to be used for advertising, publication, or promotional purposes. Citation of trade names does not constitute an official endorsement or approval of the use of such commercial products. All product names and trademarks cited are the property of their respective owners. The findings of this report are not to be construed as an official Department of the Army position unless so designated by other authorized documents. 


\section{Contents}
Abstract ii

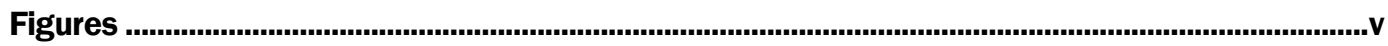
Preface ........................................................................................................................................................



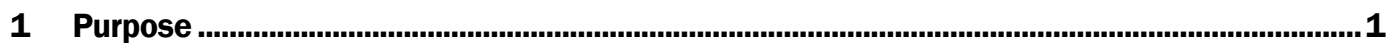

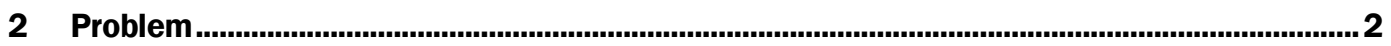

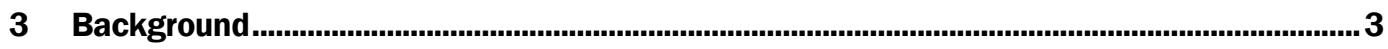

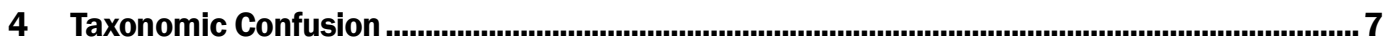

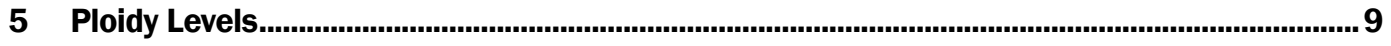

Why Should Resource Managers Be Concerned about Ploidy Levels? .............................. 10

Ludwigia peploides (Kunth) P. H. Raven........................................................................... 10

Ludwigia peploides Subspecies ................................................................................. 11

Ludwigia grandiflora (Michx.) Greuter \& Burdet............................................................. 12

Ludwigia hexapetala (Hook. \& Arn.) Zardini, H. Y. Gu \& P. H. Raven ................................... 12

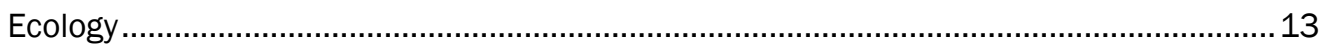

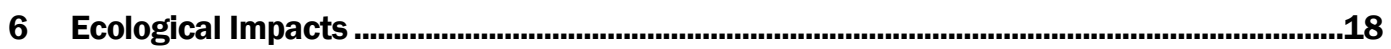

7 Economic and Human Health Impacts .................................................................................20



Russian River Watershed, California ...................................................................... 23

Kissimmee Chain of Lakes, Florida .......................................................................... 24

Santee Cooper Lakes, South Carolina ........................................................................ 25

American Heritage River: St. Johns River, Florida ..................................................... 25

American Heritage River: Willamette River, Oregon ..................................................26



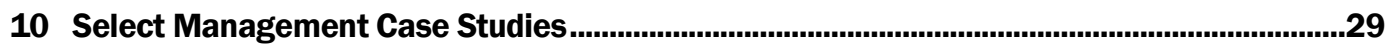

Peconic River, New York ...................................................................................... 29

Laguna de Santa Rosa, Sonoma County, California........................................................29

Colusa West Lateral Canal, Sacramento Valley, California .................................................30

Delta Ponds, City of Eugene, Willamette River Watershed, Oregon .................................. 31

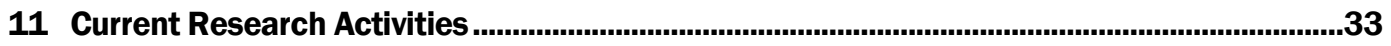

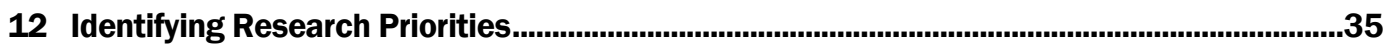




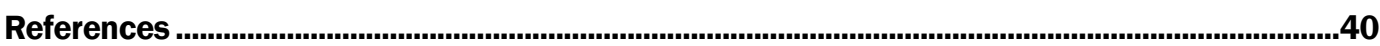

Report Documentation Page 


\section{Figures}

\section{Figures}

Figure 1. Ludwigia peploides (Top row: a. Putah Creek, b. Lake Cleone and c. Lake Hennessey, California), Ludwigia grandiflora (Middle row: d-f. Lake Tohopekaliga, Kissimmee Chain of Lakes, Florida); and Ludwigia hexapetala (Bottom row: g-h. Russian River, California and i. Oroville Wildlife Area, California).

Figure 2. Photomicrographs (1,000x) of mitotic chromosome preparations of floating root tip cells from Ludwigia peploides $(2 n=16)$, Ludwigia grandiflora $(2 n=48)$, and Ludwigia hexapetala $(2 n=80)$ from invasive populations in California.

Figure 3. The invasive Ludwigia hexapetala in California: a) Russian River; b) spring growth, Laguna de Santa Rosa floodplain; c) Feather River floodplain at Oroville Wildlife Area; d) as a submersed aquatic plant in swift current, Russian River; e) seasonal wetland, Colusa National Wildlife Refuge; f) Oxbow (Packer Lake), Sacramento River National Wildlife Refuge; and Ludwigia grandiflora in: g) floating island in Kissimmee Chain of Lakes, Florida; h) Kumeyaay Lake (flooded gravel pit), San Diego River, California.

Figure 4. Summer biomass (g DW m-2) of Ludwigia hexapetala (LUHE) and L. peploides (LUPE) sampled in $50 \mathrm{~cm}$ deep water above and below the water surface of ten shallow lakes in northern California.

Figure 5. Examples of economic and societal problems caused by invasive water primroses: a) flood control channels at Rohnert Park, California. High-density infestation of L. hexapetala is bright green, and it reduces flood retention capacity; b) Ludwigia peploides, irrigation canal San Joaquin Valley, CA; c) federal water supply canal pretreatment of L. hexapetala, Colusa National Wildlife Refuge, CA; d) L. hexapetala in rice, Butte County, CA; e) mosquito monitoring at Laguna de Santa Rosa, CA; f-g) costly mechanical removal at Kissimmee Lakes, FL; and $\mathrm{h}$ ) herbicide application in a water conveyance.canal.jn.CA.

Figure 6. Spatial distribution of invasive Ludwigia hexapetala on the Healdsburg (patchy) and Asti (continuous bands) reaches of the Russian River, approximately 120 km (75 miles) north of San Francisco, California.

Figure 7. Pretreatment conditions, hand removal and spot herbicide applications to invasive Ludwigia hexapetala at Delta Ponds Natural Area, Eugene, Oregon. Photo credit: Lauri Holts 


\section{Preface}

This study was a joint effort between the U.S. Army Engineer Research and Development Center (ERDC) and the U.S. Department of Agriculture (USDA), Agriculture Research Service (ARS) under the Aquatic Plant Control Research Program (APCRP). The APCRP is sponsored by Headquarters, U.S. Army Corps of Engineers (HQUSACE), and is assigned to ERDC under the purview of the Environmental Laboratory (EL), Vicksburg, Mississippi. The APCRP is managed under the Civil Works Environmental Engineering and Sciences Office, Dr. Alfred F. Cofrancesco, Technical Director. Dr. Linda S. Nelson is Program Manager of the APCRP.

Principal Investigator for this study was Dr. Michael D. Netherland of the Environmental Processes Branch (EPP) of the Environmental Process and Effects Division (EP), U.S. Army Engineer Research and Development Center, Environmental Laboratory. At the time of publication, Dr. Brandon Lafferty was Chief, CEERD-EPP; Warren Lorentz was Chief, CEERD-EP; the Deputy Director of ERDC-Environmental Laboratory was Dr. J ack Davis (CEERD-EZB), and the Director was Dr. Beth Fleming (CEERD-EZA). This work was conducted and the report prepared by Dr. Brenda Grewell and Meghan J . Skaer Thomason, USDA-ARS (Davis, CA), and Dr. Netherland, EPP.

Conduct of this study would have been impossible without the participation of multiple personnel with a common interest in protecting aquatic habitat from the spread of invasive plant species. The authors wish to express their gratitude to various academicians, local, state, and Federal agencies, and non-governmental organizations that have contributed information for this study.

COL Bryan S. Green was the Commander of ERDC, and Dr. J effery P. Holland was the Director. 


\section{Unit Conversion Factors}

\begin{tabular}{|l|c|l|}
\hline Multiply & By & To Obtain \\
\hline cubic yards & 0.7645549 & cubic meters \\
\hline feet & 0.3048 & meters \\
\hline inches & 0.0254 & meters \\
\hline miles (U.S. statute) & $1,609.347$ & meters \\
\hline square inches & $6.4516 \mathrm{E}-04$ & square meters \\
\hline square miles & $2.589998 \mathrm{E}+06$ & square meters \\
\hline
\end{tabular}




\section{Purpose}

The purpose of this technical report is to:

- Provide resource managers with background information on invasive, aquatic Ludwigia species, especially those located in Pacific States and Florida,

- Inform resource managers and policymakers why the current aggressive spread of Ludwigia should be a matter of concern,

- Supply resource managers with a list of research and management priorities that will serve to address information gaps on water primroses, guide actions required to prevent further introductions, effectively respond to invasions, and encourage innovative approaches to this problem.

As aquatic Ludwigia species increasingly invade and displace critical habitat and degrade a range of aquatic and riparian ecosystems, we suggest a comprehensive research approach to develop and demonstrate relevant management strategies to counter this growing problem.

While water primroses have been present in the United States (U.S.) for decades, the recent rate of spread in crucial water bodies in states such as California and Florida, and the longer-term experience in France, is of significant concern. How should we respond to a rapidly emerging problem in the midst of numerous other invasive plant priorities? The timely answer to these questions is of paramount importance to resource managers, policy makers, and stakeholders throughout Pacific, Gulf, and Atlantic coastal states. 


\section{Problem}

The increased spread of invasive plant species is a significant aspect of human-induced global change (Vitousek et al. 1997). In aquatic ecosystems, increases in the numbers of invasive weed species and their abundance have been linked to global trade, eutrophication of water, and changing climate (Lodge et al. 1998, Hussner 2009). Creeping water primroses and water primrose-willows are among the most aggressive, aquatic, invasive plants in the world. (Thiébaut and Dutartre 2009, Thouvenot et al. 2013a). Epidemic populations are increasingly problematic in the south Atlantic, Gulf, and Pacific west coastal United States, making for significant economic and ecological impacts. While the need for management approaches has become an important topic, the distribution of different species and their response to varying environmental conditions in the U.S. is limited. This biological and ecological information is the foundation for risk assessments and effective management. Likewise, it is important for predicting additional spread of invasive aquatic plants. 


\section{Background}

Aquatic and riparian ecosystems are highly susceptible to invasion by nonindigenous, aquatic plants. Uruguayan primrose-willow (Ludwigia hexapetala), large-flowered primrose-willow (Ludwigia grandiflora), and creeping water primroses (Ludwigia peploides) are aggressive weeds in the evening primrose family Onagraceae. These species are degrading major watersheds in California and Florida as well as aquatic and riparian ecosystems in the Pacific Northwest, Atlantic, and Gulf coastal states by clogging lakes, ponds, irrigation canals, flood control channels, riverine, and other sensitive wetlands, and invading rice fields. These same Ludwigia species are also a problem in Australia, New Zealand, Turkey, and throughout Europe; in France they are now by far the most invasive alien, aquatic plant species (Thouvenot et al. 2013a). These three emergent macrophytes in the Ludwigia genus are commonly called "creeping water primroses" given their tendency for rooted, buoyant shoots that quickly grow to the water surface and form impenetrable mats with floating leaves (Figure 1a-c). Some species, such as L. grandiflora (Figure 1d - f) and L. hexapetala (Figure 1g-i), develop woody, willow-like stems (Figure 1e) and woody rhizomes (Figure $1 \mathrm{~h}$ ) in their tall emergent forms and are commonly known as "water primrose-willows."

Exploration and import of ornamental plants for estate gardens and ponds dates to the early $17^{\text {th }}$ century in Europe, late $17^{\text {th }}$ century in the U.S., leading to many plant species that naturalized and became invasive (Reichard and White 2001). In 1733, English colonists established a plant introduction station and botanical gardens in Savannah, Georgia. They also imported seeds and exotic plants from Central and South America to test as medicinal plants, use as natural dyes, and plant crops for production and for export to England. In 1737, colonists established the first commercial nursery in New York to conduct international trade of ornamental plants. The establishment of botanical gardens in eastern states soon followed. Seeds and extractions from plants were often exchanged and sold to nurseries. By the early 1800's, global exploration and trade in ornamental and aquarium plants had grown, and plant importation was common and quite popular (Reichard and White 2001). Carl Linnaeus, the father of plant taxonomy, was the first to classify Ludwigia specimens in the $18^{\text {th }}$ century. He named the genus in honor of Christian Gottlieb Ludwig, an $18^{\text {th }}$ century botanist and professor of medicine at the University of Leipzig, Germany (Linnaeus 1737). 
Figure 1. Ludwigia peploides (Top row: a. Putah Creek, b. Lake Cleone and c. Lake Hennessey, California), Ludwigia grandiflora (Middle row: d-f. Lake Tohopekaliga, Kissimmee Chain of Lakes, Florida); and Ludwigia hexapetala (Bottom row: g-h. Russian River, California and i. Oroville Wildlife Area, California).
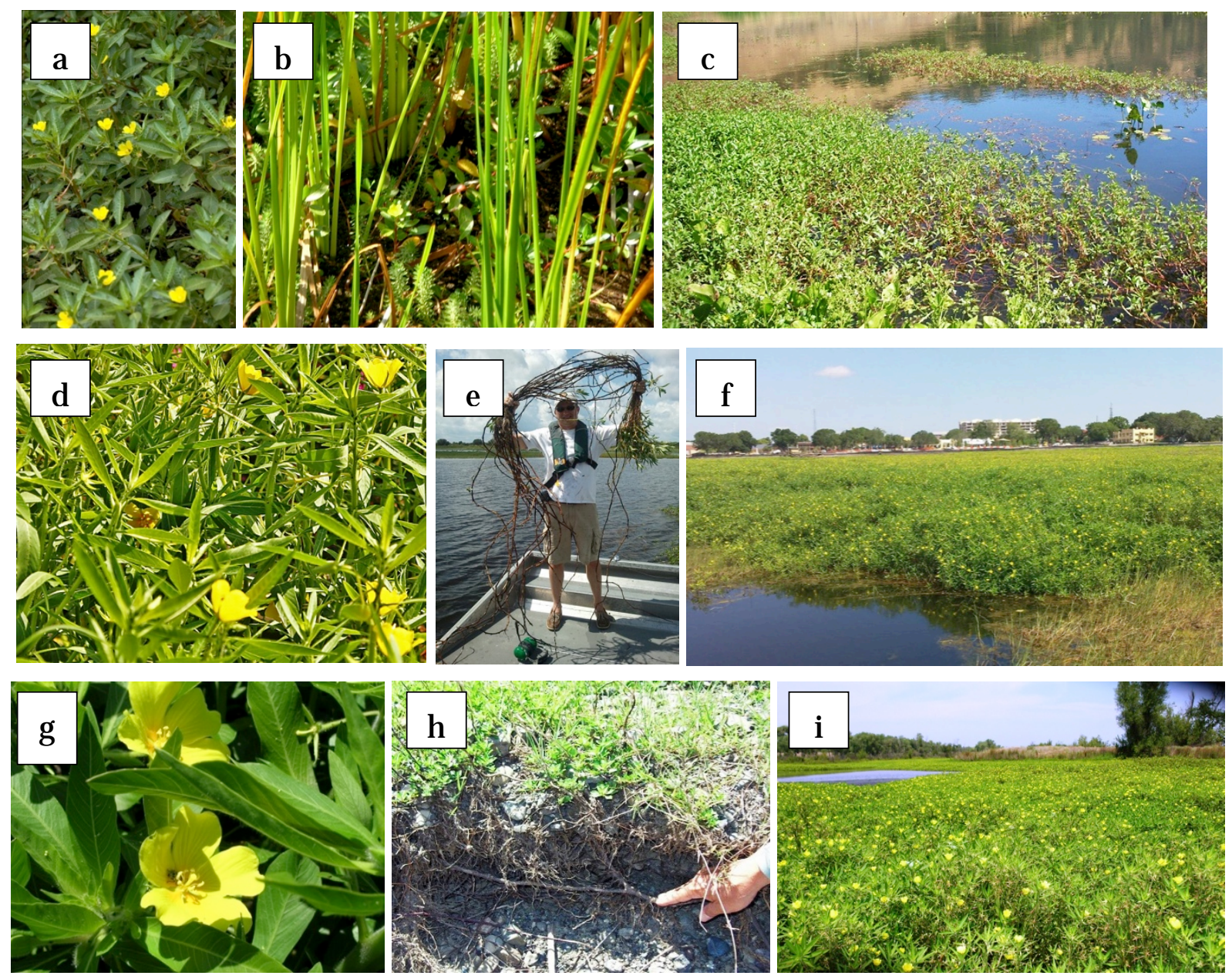

In $19^{\text {th }}$ century France, legacy horticultural introductions of L. hexapetala (syn. L. grandiflora subsp. hexapetala) as an ornamental plant were documented with an intentional introduction in 1830 to the Lez River at Montpellier (Martins 1866) and naturalization from a botanical garden near Bordeaux in 1882 (Guillaud 1883, Dandelot et al. 2005b). While some thought these aquatic species may be native to Florida and other south Atlantic states, legacy horticultural introductions of aquatic L. hexapetala in South Carolina in 1844 and in Georgia in 1864 may be an alternate explanation, given their disjunct distribution from the putative native range of the genus in southern South America and the popularity of ornamental introductions for water gardens and aquaria during the $19^{\text {th }}$ century. There is great uncertainty regarding native vs. non-native status of Ludwigia species in the southeastern U.S. Although molecular analyses of the Ludwigia family are incomplete, they are needed to keep managers abreast 
of the growing concerns with this species and resolve phylogenetic and taxonomic questions (Wagner et al. 2007). There has never been any question that the early $19^{\text {th }}$ century horticultural introductions formed naturalized populations in the south of France that persisted locally and then spread into south and western France. In the 20th century, increased use for ornamental plantings accelerated their spread in Europe (Dandelot et al. 2005b). In fact, it is highly likely that multiple introductions occurred. In the last three or four decades, L. hexapetala has aggressively spread northward throughout France and more recently into the UK, Ireland, Belgium, the Netherlands, Italy, Spain, and Greece (Thouvenot et al. 2013a). It is interesting to note that a substantial time lag in invasiveness has been noted for L. hexapetala in south Atlantic states. An aggressive spread of L. grandiflora has recently affected sensitive wildlife habitats in the Kissimmee Chain of Lakes of Central Florida (J acono 2014). Cytogenetic evaluation has confirmed L. hexapetala (chromosomes $2 n=80$ ) in Lake Harney on the Saint J ohns River, while L. grandiflora $(2 n=48)$ has been confirmed in Lake Tohopekaliga and Lake Poinsett (Grewell and Netherland, unpublished data).

Ludwigia hexapetala is a relatively recent invader in Pacific western states with the earliest records dating back to the 1940's in Tiburon and San Diego, California. A voucher specimen collected near Corvallis, Oregon documented an introduction in 1940 when a "fish bowl" was emptied into a slough connected to the Willamette River. Intentional introduction via emptying of aquaria into flood control channels near Longview also explains the 1955 introduction to Washington. As previously mentioned for the southeast, there was a lag of 50 to 60 years before these populations spread to the extent that they were recognized as aggressive weeds that displace native plant communities.

In the $20^{\text {th }}$ century, Ludwigia peploides was introduced as an ornamental plant in southern France, and it has since spread northwest to the Loire River; however, the distribution is scattered and more geographically limited than the more widely spread L. hexapetala in France (Dandelot 2005b). In the western U.S., L. peploides was the first to arrive. The earliest herbarium specimens were collected from 1863-1893 from scattered sites in northern California. During the $20^{\text {th }}$ century, they spread into the San J oaquin Valley and southern California. Although invasive populations are being managed in Portland, Ludwigia peploides is still rare in Oregon, with only a few confirmed records. There is a single 
disjunct record of L. peploides in Washington from invasion of a wetland restoration site near Seattle. L. peploides was observed as a naturalized invasive weed in the Peconic River, New York in 2003 and became the target of a successful education and eradication effort. L. peploides is a weed in rice fields of Australia, California (McIntyre and Barrett 1985), Chile (Ramirez et al. 1991), and Argentina (Sabattini et al. 1998). Movement of rice seeds for cultivation could possibly be a pathway for introductions of L. peploides from South America.

During the $20^{\text {th }}$ century, increased use of Ludwigia spp. as ornamental aquatic plants accelerated their spread in Europe (Dandelot et al. 2005b) and in the U.S. Recently, international focus has sharpened on the critical need for effective management approaches due to the exponential growth and spread of aquatic water primroses to nuisance proportions in nearcoastal regions of the U.S. and Europe. Unfortunately, aquatic water primroses and primrose-willows are still sold as decorative plant species for water gardens and aquaria. While some states regulate their sale and transport, others sale live Ludwigia plants in their local garden centers. Likewise, national and international internet sources make live plants and seeds readily available. 


\section{Taxonomic Confusion}

Management of invasive water primrose species, like other invasive plants, must be grounded in basic knowledge of the biology and ecology of the species and their responses to environmental conditions. These important factors can vary tremendously among related taxa and may require different management approaches. Therefore, the first step in an invasive species management program requires accurate identification. The morphology of aquatic water primrose species can be highly variable in response to local environmental conditions, making proper identification difficult and further perpetuating taxonomic confusion in both the U.S. and Europe (Harper 1904, Munz 1942, Dandelot et al. 2005b). The nomenclature herein follows Wagner et al. (2007) and Hoch and Grewell (2012).

Ludwigia is an ancient genus of plants that originated between 93 and 80 million years ago in the Cono Sur of South America (Wagner et al. 2007). The pantropical Ludwigia genus includes 82 species (with subspecies, 87 taxa) that are taxonomically divided into 23 major sections (Zardini et al. 1991b). Ludwigia is the center of origin and basal lineage of the entire monophyletic evening primrose family, Onagraceae. The greatest diversity of species are found in southern South America (Wagner et al. 2007). Ludwigia species in section J ussiaea (Hoch et al. 2015) are largely aquatic, morphologically similar, but vary in ploidy levels. There has been a long history of taxonomic revisions of these three focal Ludwigia species. Species in this section are all perennial herbs with terete stems, floating, emergent, or erect leaves that ascend through spongy, arenchymous bases (Wagner et al. 2007). The plants root in sediment, form spongy white pneumatophores (aerial roots) in shallow water that supply oxygen to the plant allowing it to survive anoxic conditions (Ellmore 1981), and root extensively in the water column from floating stem nodes. Leaves are alternate, and leaf blades have a sub-marginal vein. The plants flower through summer The diurnal flowers typically have five to six yellow petals and twice as many stamens as sepals. The sepals are persistent after flower petals have dropped. Reproduction is by both seeds and asexual fragments. While they share these traits, the morphology of the three introduced Ludwigia species is extremely plastic in response to environmental conditions. Nearly all species of Ludwigia in section J ussiaea can be crossed with one another and produce vigorous $\mathrm{F}_{1}$ hybrids (Zardini et al. 1991b). New hybrids can be expected in nature. 
Hybridization between invasive weeds can improve performance and vigor, thus further increasing invasiveness (Gaskin and Schaal 2002, Ellstrand and Schierenbeck 2006). Some species in the section, including L. hexapetala, L. grandiflora, and L. peploides, have become major invasive weeds in their non-native, naturalized range. 


\section{Ploidy Levels}

The base number of chromosomes in Ludwigia is $n=8$. Chromosome numbers in the polyploid J ussiaea section include $\mathrm{n}=8,16,24,40$, and 48 (Zardini et al. 1991a). Differentiation of L. hexpetala and L. grandiflora, previously known as the L. uruguayensis complex, must be based on a combination of field observations of growth characteristics, morphological evaluation of fresh specimens, and chromosome numbers (Zardini et al. 1991a). Nesom and Kartesz (2000) evaluated voucher specimens in two herbaria, compared these with Zardini's herbarium specimens, observed overlapping characters, and proposed to recognize L. hexapetala as a subspecies, L. grandiflora subsp. hexapetala (Hook. \&Arn.) . More recently, others have utilized numerous voucher specimens from throughout the native and invasive range, extensively observed populations in the field, and conducted morphometric evaluations of fresh specimens, chromosome counts, and genetic studies to distinguish L. hexapetala, L. grandiflora, L. peploides (Wagner et al. 2007, Hoch and Grewell 2012), and new aggressive hybrids (Okada et al., unpublished data). Ploidy level refers to the number of sets of chromosomes in the nucleus of a biological cell. Evolutionary events that increase Ludwigia chromosome sets can lead to new species. Ploidy levels of Ludwigia invaders vary by species. Ludwigia peploides, and recognized subspecies, is diploid ( $2 \mathrm{n}=16$ chromosomes), $\mathrm{L}$. grandiflora is hexaploid ( $2 \mathrm{n}=48$ chromosomes), $\mathrm{L}$. hexpetala is decaploid $(2 \mathrm{n}=80$ chromosomes) as shown in Figure 2.

Figure 2. Photomicrographs (1,000x) of mitotic chromosome preparations of floating root tip cells from Ludwigia peploides $(2 n=16)$, Ludwigia grandiflora $(2 n=48)$, and Ludwigia hexapetala $(2 n=80)$ from invasive populations in California.
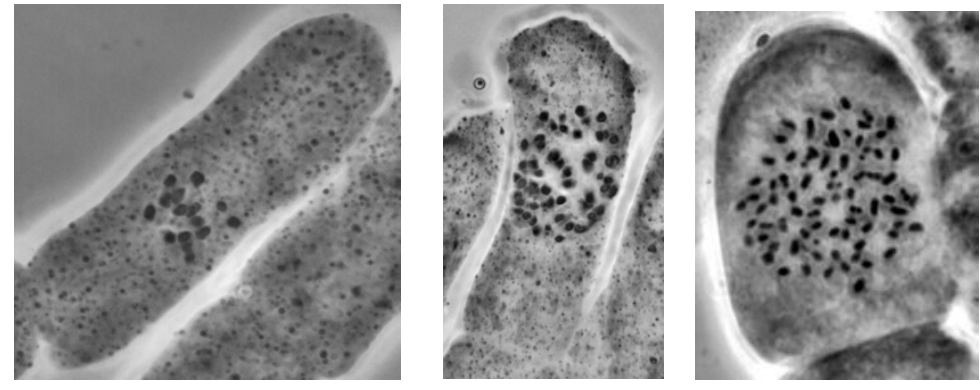


\section{Why Should Resource Managers Be Concerned about Ploidy Levels?}

Aside from use for identification purposes, why should resource managers be concerned about the chromosomal data and ploidy levels of these species? There is increasing evidence that fitness (i.e., increased biomass production and reproductive output) and the adaptive ability of plants increase with increasing ploidy levels. Recent analyses have produced strong evidence that there is a positive relationship between chromosome numbers and ploidy levels of plant species and their degree of invasiveness through increased speed of cell division, gene redundancy, and increased phenotypic variation (te Beest et al. 2012, Pandit et al. 2014). For example, some polyploid species have increased ion uptake rates and are more tolerant of salinity and drought than related diploid species (Hollister 2014). In a practical sense, higher phenotypic plasticity of polyploids suggests that L. hexapetala may be better equipped to adjust to changing climate and environmental conditions, which may explain its superior ability to spread as compared to L. peploides. In a management context, this also suggests that integrated approaches to management of polyploid species of Ludwigia will be more challenging than management of $\mathrm{L}$. peploides, and managers will need to know what species they are targeting in order to recommend the appropriate management technique.

\section{Ludwigia peploides (Kunth) P. H. Raven}

(synonyms (syn.): J ussiaea repens, J . r. var. montevidensis, J. r. var. glabrescens, J . californica, J . r. var. californica, J . r. var. peploides, $\mathrm{J}$. diffusa; creeping water primrose) includes at least three subspecies that have been somewhat defined morphologically and geographically. Ludwigia peploides is diploid and can be distinguished from other Ludwigia species by chromosome numbers $(2 \mathrm{n}=16)$. Taxonomic distinction by morphology is also possible during the reproductive stage of the life cycle. The flowers of L. peploides are smaller than those of the polyploid species and usually have 10 stamens. The yellow, upturned petals of the flowers are typically 7-16 $\mathrm{mm}(\sim 0.3-0.6$ inches) long and fruit capsules can be $\sim 10-30 \mathrm{~mm}$ (0.4-1.2 inches) long. Sepals are persistent on capsules after petal drop. For comparison, petals of $\mathrm{L}$. grandiflora may be 15-20 mm (0.6 - 0.8 inches) long, while petals of $\mathrm{L}$. hexapetala are typically much larger. Petals of L. hexapetala are the largest, often measuring 20-29 mm (0.8-1.1 inches) long. Ludwigia peploides plants are self-compatible, and pollinating bees are frequent floral visitors. Bracteoles (or "bractlets") near the base or up to the middle 
of the ovary are usually dark green, deltoid-squamate, and $0.5-1 \mathrm{~mm}$ (0.02-0.04 inches) long. These bracteoles, as well as other distinguishing characters, are best examined on fresh specimens, as they often shrivel, break easily, and are often missing on dry voucher specimens. The buoyant shoots of plants float on the water or on stolons root from nodes as they creep across wet soil. By comparison, the canopy height of populations is much less than observed in L. hexapetala or L. grandiflora populations. Plants can form dense colonies in standing water and slightly above the water line.

\section{Ludwigia peploides Subspecies}

L. peploides (Kunth) Raven subsp. peploides is found in Argentina, Paraguay, and Brazil where it is native. Specimens document the taxa in Nicaragua and Australia where it has been reported as introduced. It is also found in the western U.S. from California to Texas where it was long thought to be native; however, the existence of hybrids between other subspecies and molecular evidence from naturalized California specimens suggest a South American origin (Okada et al. unpublished data). This taxon is typically glabrous, and the leaf apex is not mucronate or glandular-mucronate. Ludwigia peploides (Kunth) Raven subsp. glabrescens (Kuntze) Raven occurs disjunctly in the U.S. and Eastern Asia and has long been considered native in the eastern, southeastern, and western U.S. including Texas where its range overlaps with L. p. subsp. peploides. However, we have observed L. p. subsp. glabrescens in Argentina, purchased live specimens from internet sellers, and suspected its disjunct presence in the U.S. may be a naturalized occurrence. The L. p. subsp. glabrescens has glossy or shiny green leaves with a glabrous upper surface, while the underside of the leaf is glabrous to sparsely pubescent. Ludwigia peploides (Kunth) Raven subsp. montevidensis (Spreng.) Raven is known to southern South America (Argentina, Uruguay, and southern Brazil) where it is native. It is widely recognized as introduced in disjunct, naturalized populations found in California, Louisiana, Oregon, and also in Cuba, Belgium, France, Italy, the Netherlands, Portugal, Spain, Switzerland, the United Kingdom (UK), Australia, and New Zealand. In South America and California, L. p. subsp. montevidensis is densely pubescent, while it is described as glabrous in Australia. The leaf apex is commonly mucronate. Recent molecular analyses confirm that naturalized populations of L. p. subsp. montevidensis in California are closely related to a native genotype in Uruguay, and hybrids between L. peploides subspecies that are present in California (Okada et. al, in prep.) likely 
occur elsewhere. Differences in environmental tolerances among the subspecies are unknown, but the three diploid taxa are predicted to be ecologically more similar to each other than to the polyploid invaders.

\section{Ludwigia grandiflora (Michx.) Greuter \& Burdet}

(syn. Ludwigia uruguayensis, J ussiaea uruguayensis, J . michauxiana, J . grandiflora; large-flowered primrose-willow), occurs in the southeastern United States from the piedmont and coastal plain of southern South Carolina to coastal Georgia and northern Florida. It is also found in western Louisiana and appears in coastal and central Texas as well. The species is native to central and southern South America from south of the Amazon basin in Brazil to Uruguay, with most collections spotted in Brazil and Paraguay. Disjunct populations have been collected three times in Guatemala and once in Missouri (Wagner and Hoch 2005). The perennial herb to woody sub-shrub can be floating or creeping in water although the emergent shoot can be quite erect and ascending. The plants have been described as densely villous, but at times they are sparsely pubescent to near glabrous. Green triangular-shaped bracteoles are observed at the base of petioles in some populations, and lanceolate-shaped bractioles are found on the ovary. Leaves are highly variable in shape, and leaf apices are often mucronate. Capsules are villous to densely villous with hairs up to $1 \mathrm{~mm}$ long. Capsules are highly variable in size (11-25 mm; 0.4-1 inches long), truncate at the apex, and narrowed towards the pedicel. There are 815 seeds per locule in a wedge shaped piece of endocarp embedded in the woody capsule. Chromosome numbers of the hexaploid species are $2 n=48$, and interploid hybrids between L. grandiflora and L. hexapetala, and L. grandiflora and L. hookeri are also reported where the range of the species overlap (Zardini et al. 1991b).

\section{Ludwigia hexapetala (Hook. \& Arn.) Zardini, H. Y. Gu \& P. H. Raven}

(syn. Ludwigia grandiflora subsp. hexapetala, L. uruguayensis, L. u. var. major, J ussiaea uruguayensis var. major, J . michauxian, J . repens var. major, J . hexapetala; Uruguayan primrose-willow) is native to southern South America (southern Brazil, eastern Paraguay, Argentina, and Uruguay). Morphological characters suggest L. hexapetala may be the product of hybridization between L. grandiflora and L. hookeri in the native range, but molecular studies are needed for confirmation (Zardini et al. 1991a,b). Populations in Costa Rica, west of the Andes in Chile, and in Peru are considered introduced (likely by shipping commerce) and 
naturalized, while introductions to Ecuador and Columbia are documented (Wagner et al. 2007, Wagner and Hoch 2005). Ludwigia hexapetala is also naturalized in coastal states of the U.S. In the Atlantic region, it has been collected at a few locations in Pennsylvania, New York, and Alabama, but the primary range is the southeast Atlantic states from the Carolinas to Florida. Ludwigia hexapetala is also naturalized and highly invasive in France, Belgium, Spain, and the UK.

Like L. grandiflora, L. hexapetala can be a creeping perennial herb in shallow water, or it can be a woody sub-shrub becoming more ascending and erect near and above the water's edge. Shoots can be $>2$ meters tall in eutrophic areas, and sometimes twine up the trunks of woody shrubs and trees at water's edge. It roots from buoyant stem nodes and has the ability to produce thick masses of adventitious roots. All parts of the shoot can be strongly villous, though submersed portions of stems tend to be glabrous. Leaf shapes are not diagnostic and vary tremendously with environmental conditions and life stage. Pre-reproductive leaves are often rounded and in clusters, while mature leaves and emergent leaves vary widely from oblanceolate to narrowly elliptic. Mucronate tips at leaf apex can often be observed without magnification. Many flowers are produced on shoots. Petals (5-6) are typically yellow, but can be light orange and are usually $>25 \mathrm{~mm}$ long (>1 inch), but can be $20 \mathrm{~mm}$ (0.8 inches) long and even as short as $11 \mathrm{~mm}$ ( 0.4 inches ) in rocky dry areas where entire plants grow and flower in stunted form. Sepals can be green to reddish, and are pubescent and persistent after petal drop. Woody capsules are irregularly or tardily dehiscent as described for the other species and are typically 14$26 \mathrm{~mm}$ (0.6 - 1 inch) long and sparsely pubescent. Capsule shape is variable from straight to slightly curved-terete, truncate at the apex, and narrows toward the base. Bracteoles at the base of the ovary or part way up the pedicel are lanceolate, narrow or wide obovate, acute in shape or sometimes acuminate or attenuate at the apex, persistent, 1-1.8 mm (0.040.07 inches) long, $0.7-0.8 \mathrm{~mm}$ ( $\sim 0.03$ inches) wide, and color ranges from green to dark brown. Chromosome numbers of the decaploid species are 2n=80 (Zardini et al. 1991b).

\section{Ecology}

Studies of aquatic plant species in the native South American range of water primroses have largely focused on floristic surveys, composition, structure, and successional dynamics of vegetation that includes Ludwigia spp. in wetland areas of southern Brazil (Rolon et al. 2008, Maltchik et al. 2010) and in the Paraná River watershed (Sabattini and Lallana 2007). In 
southern Brazil, L. peploides is a member of wetland plant communities with high diversity of macrophyte and -macroinvertebrate species (Maltchik et al. 2010). The expansive Paraná River watershed is a dynamic, lentic system characterized by recurring flood pulses over short temporal scales that reset successional processes in the river system (Sabattini and Lallana 2007). Aquatic Ludwigia spp. have been reported from flowing rivers, low flow backwater channels of rivers, lagoons isolated from the primary river channel, perennial and seasonal wetlands, temporary ponds and lakeshores to the marginal high water line with distribution and abundance highly related to the hydrological regime (Sabattini and Lallana 2007). They are also reported from "baceiros, verdolagales, embalsados and camalotes" which are associations of aquatic plants that form floating islands that drift with flood pulses and spatially rearrange the associated ecological system in rivers and lakes (Pivari et al. 2008). Similar patterns of invasive L. grandiflora growth have been observed in the Kissimmee Chain of Lakes, Florida.

To date, the bulk of published scientific studies on the ecological and economic impacts of naturalized water primrose populations have come from France and nearby European countries with a long history of invasion. In France, L. hexapetala has colonized slow-flowing aquatic ecosystems, gravel and mud river banks, peat soils, ditches, sand bars, natural and artificial lakes and ponds, flooded gravel pits, oxbow channels, and wet meadows (Lambert et al. 2010, Thouvenot et al. 2013a). This tolerance to a wide range of environmental conditions has also been observed in the U.S. and suggests that the species has high phenotypic and morphological plasticity that allows it to survive, colonize, and invade novel habitats (Figure 3).

In France, L. peploides is self-compatible and produces many seed capsules and seeds; L. hexapetala, on the other hand, outcrosses, has variable capsule production, and contains sterile populations. (Dandelot et al. 2005a). High seed output of 10,000 seeds/ $\mathrm{m}^{2}$ is reported for $\mathrm{L}$. peploides and L. hexapetala from the Loire River, France (Dandelot 2004). Clonal spread through asexual reproduction is the primary regeneration mode of $\mathrm{L}$. hexapetala and L. grandiflora in California. Floating ramets (stem fragments with rooted nodes) can rapidly spread over great distances and establish new populations throughout watersheds (Okada et al. 2009). Sexual reproduction is another mode utilized by all three taxa in California with L. hexapetala and L. grandiflora being predominantly outcrossers. To date, managers in western states have not observed sterile populations of any of the species, however, hybrids are present (Okada et al. unpublished data). 
Figure 3. The invasive Ludwigia hexapetala in California: a) Russian River; b) spring growth, Laguna de Santa Rosa floodplain; c) Feather River floodplain at Oroville Wildlife Area; d) as a submersed aquatic plant in swift current, Russian River; e) seasonal wetland, Colusa National Wildlife Refuge; f) Oxbow (Packer Lake), Sacramento River National Wildlife Refuge; and Ludwigia grandiflora in: g) floating island in Kissimmee Chain of Lakes, Florida; h) Kumeyaay Lake (flooded gravel pit), San Diego River, California.
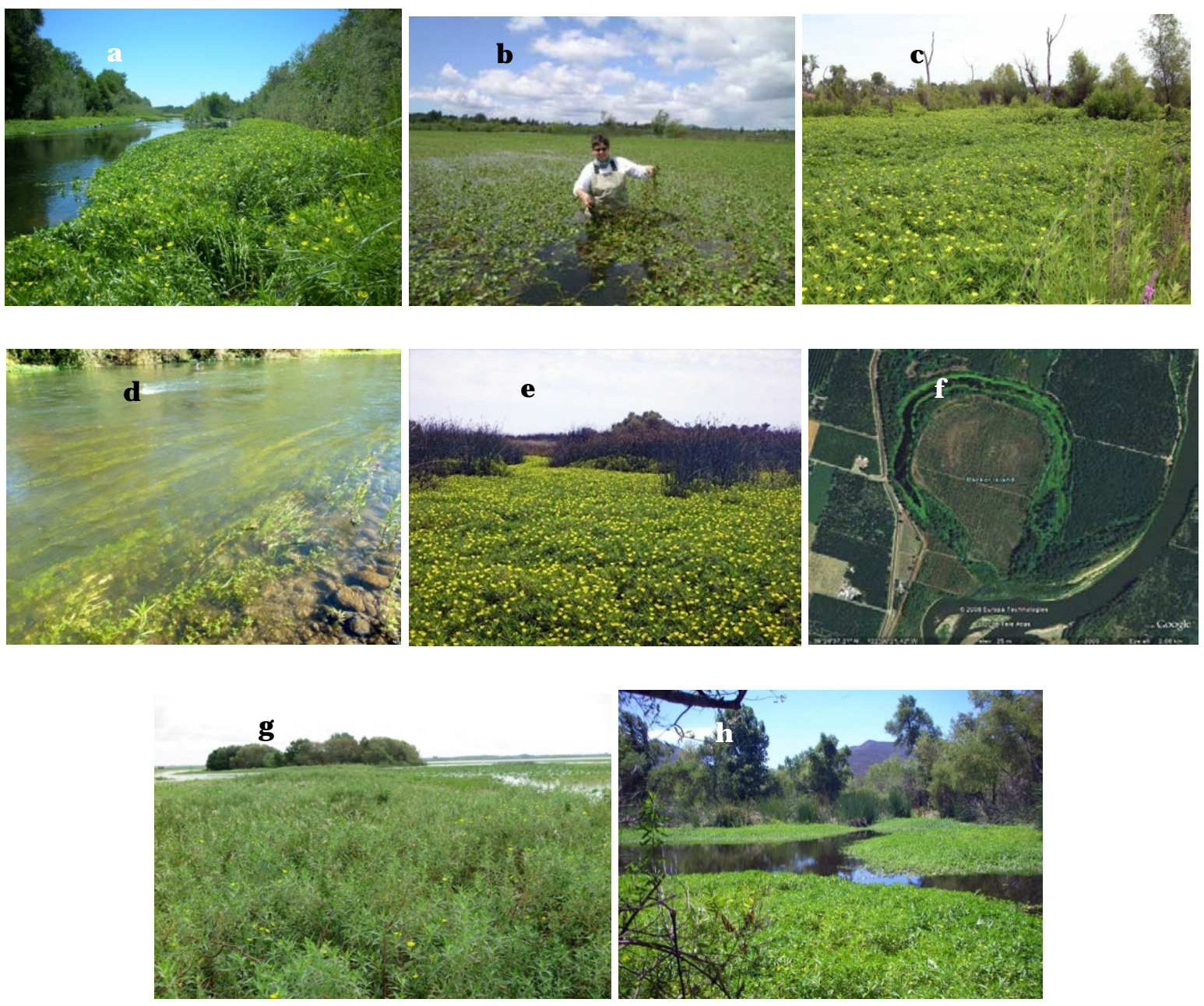

The primary drivers of aquatic plant growth are hydrology, nutrient and light regimes, temperature, and biological interactions. These are all spatially variable factors throughout the native and naturalized range of the plants. In addition, researchers know very little about the degree to which each species can adjust or has genetically adapted to variation in climate and other environmental conditions. Ludwigia spp. have preferentially colonized slow and stagnant water habitats in France (Thouvenot et al. 2013a), and researchers and resource managers have observed similar patterns in Pacific west states. However, L. hexapetala has also persisted and spread below cold-water reservoir release points into the Russian River where currents can be swift. In these cases, the plants adjust their growth form, grow closer to the riverbank, and grow 
more erect to resemble hedgerows where they are less impacted by the fast current. If flow rates are reduced during the active growing season, they again grow long buoyant shoots that creep across the still to slow moving water surface. Managers have also observed L. hexapetala as a submersed aquatic plant in both still and moving river water (Figure 3d). Water depth is another ecological variable that influences growth of Ludwigia spp. Ludwigia hexapetala and L. peploides are most often found from $0.6 \mathrm{~m}$ ( 2 feet) above standing water to $1 \mathrm{~m}$ (3.3 feet) deep, but they tolerate depths up to $3 \mathrm{~m}$ (9.8 feet) and are also found at greater distances upslope from standing water (Lambert et al. 2010). In Germany, studies show that biomass production and allocation vary with water depth (Hussner 2010). Mesocosm experiments, conducted with a genotype of L. hexapetala that has invaded northern France, suggest that morphological plasticity of growth varies seasonally, and the species has a high tolerance for a range of water levels and light environments though growth was highest in full sunlight and in $30 \mathrm{~cm}$ (11.8 inches) of water (Thouvenot et al. 2013b). Studies are underway in California to quantify seasonal biomass production, allocation, and carbohydrate storage reserves of L. hexapetala across nutrient and water depth gradients to better understand life cycle dynamics for improved management. Recently a synoptic sampling survey of replicated plots was conducted in ten shallow California lakes to compare the growth and impact of L. hexapetala and L. peploides. The above water impact of the infestations was readily observed (see photographs, Figure 1) and showed that the biomass production and accumulation below the water surface greatly exceeded that of the above water growth of both species. In fact, L. hexapetala produced more than three times the biomass of L. peploides (Figure 4).

In general, water primroses have high growth rates. Biomass doubling times between 15-90 days under field conditions have been reported in France (Thouvenot et al. 2013a). Rejmánková (1992) demonstrated that L. peploides from California could regenerate $67 \%$ of its biomass within 45 days after $95 \%$ of it was experimentally cut and removed. In the same study, the species was able to maintain biomass production within a wide range of nitrogen availability (Rejmánková 1992). In the Russian River watershed, L. hexapetala adapted to both high and low nutrient environments where it grew well and spread in sandy, low nutrient soils and in highly eutrophic conditions in the Laguna de Santa Rosa floodplain where the highest biomass production was observed. L. hexapetala harvesting has been useful for phosphorous removal from wastewater and for production of biogas as an energy source to power vehicles (Cohen et al. 2013). 


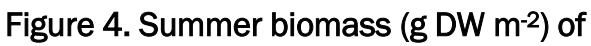
Ludwigia hexapetala (LUHE) and $L$. peploides (LUPE) sampled in $50 \mathrm{~cm}$ deep water above and below the water surface of ten shallow lakes in northern California.

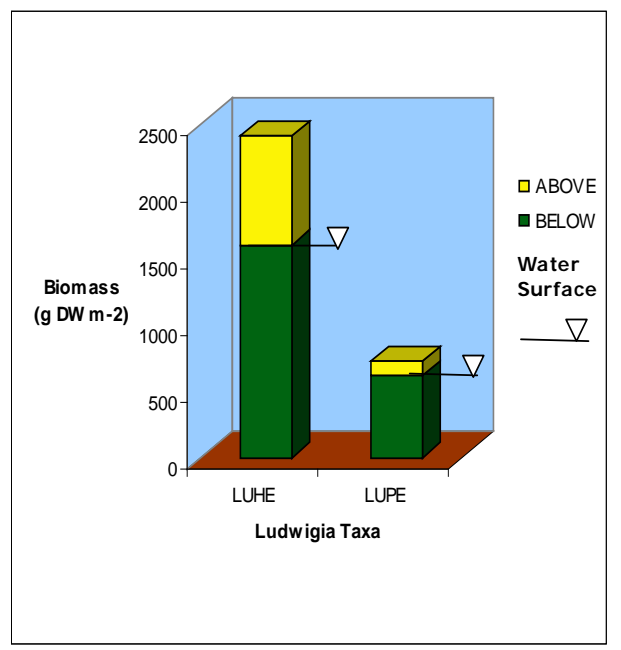




\section{Ecological Impacts}

Perennial Ludwigia species can form very dense, nearly impenetrable mats that extend below the water surface (Figure 4), across the surface, and can become herbaceous or woody thickets over the water surface. These mats intercept incoming sunlight that drives photosynthetic processes and growth and greatly decrease subsurface light conditions, thereby limiting ecologically important submersed macrophytes and algal species resulting in a change in aquatic food web structure. Once established, Ludwigia species tolerate a wide range of nutrient conditions, and local spread can be rapid due to the high growth rates of the species. When disturbed, buoyant shoots break off easily from established plants and disperse rapidly with water flow throughout watersheds to colonize downstream sites.

In the invaded range, Ludwigia spp. often competitively displace native plants, degrade water quality, and reduce or eliminate available open water habitat that is critical foraging and rafting areas for water birds and other wildlife. Greenhouse experiments suggest a complex range of intraand interspecific interactions (which vary between life stage and environmental conditions) exist between invasive L. hexapetala (reported as syn. L. grandiflora subsp. hexapetala) and native and other exotic plant species (Thouvenot et al. 2013c). For example, L. hexapetala had little impact on experimental plantings of native plant species during the early stages of L. hexapetala establishment. In fact, L. hexapetala actually facilitated the establishment of exotic Egeria densa proving that L. hexapetala and exotic Myriophyllum aquaticum could coexist under certain experimental conditions (Thouvenot et al. 2013c). These results agree with observations made in California, in settings where L. hexapetala is found at low to moderate densities within plant communities. Studies in France, Belgium, and Switzerland have quantified reductions in native plant diversity, macroinvertebrate, and fish populations because of competitive exclusion by Ludwigia species (EPPO 2011a, Nehring and Kolthoff 2011). Their alteration of plant community composition and physico-chemical characteristics of aquatic ecosystems fundamentally changed and impacted critical habitat and resident flora and fauna (Stiers et al. 2011, Thouvenot et al. 2013a). In the Sacramento National Wildlife Refuge Complex in northern California, L. hexapetala 
has invaded whole-pond systems, which are managed as seasonal wetlands, resulting in degradation of habitat quality for migratory waterfowl and other water-dependent wildlife by displacing desirable wildlife, food plants, and open water habitat.

In general, dense infestations of emergent macrophytes can dramatically reduce the dissolved oxygen (DO) concentrations in water by reducing water circulation and increasing biological oxygen demand from high biomass production and subsequent in situ decomposition of organic matter. Impacts to DO can vary with plant community composition and hydrologic conditions. When DO is reduced to low levels, the hypoxic environment may support some tolerant fish species, but many valued fish species such as bass in lakes and salmonids in coastal riverine systems experience a reduction in habitat quality. Regulation of water levels and flows in lake and river systems can provide important societal services such as flood control and water supply, but they also affect aquatic community composition and food web functions. Data from the Russian River suggests that high-density Ludwigia stands slow the flow of water, leading to increased sedimentation in the plant beds. Dense stands also reduce oxygen exchange between the atmosphere and water column and reduce light that supports important native submersed aquatic plants and aquatic food webs (EPPO 2011a). Dandelot et al. (2005a) report much lower DO levels and reduced $\mathrm{pH}$ levels associated with water primrose stands in France due to suppression of photosynthetic processes of submersed aquatic vegetation. The density of macroinvertebrates recorded in nature reserve ponds of Belgium was negatively related to the percent cover of L. grandiflora mats, likely due to anoxic conditions that limit diffusion of oxygen (Stiers et al. 2009, Stiers et al. 2011). Studies also suggest that L. peploides and L. grandiflora produce and release allelopathic chemicals that were shown to impact germination, survival, and growth of two native aquatic plants (Dandelot et al. 2008). Likewise, these compounds could negatively affect other organisms in aquatic food webs including fish and invertebrates (Schultz and Dibble 2012). 


\section{Economic and Human Health Impacts}

The European and Mediterranean Plant Protection Organization (EPPO) risk analysis for L. peploides and L. grandiflora report that these species interfere with agricultural production, ecosystem services, and human use of water bodies. These impacts include deterioration of dams and other water management infrastructure, loss of recreation areas, increase in flood risk due to reduction of channel carrying capacity, and high economic consequences incurred for control of the weeds (EPPO 2011b, 2011c). The negative ecological and economic impacts and overall risks associated with the establishment of these species in aquatic environments have prompted measures to prevent their spread. In several cases, Ludwigia spp. are regulated as noxious weeds or quarantine species, and management costs for government agencies in Europe and several U.S. states are substantial.

The high biomass production of water primrose species displaces the volumetric water capacity of important water conveyance systems including water supply canals for agricultural irrigation (Figure 5a) and wetland preserves dually managed for fish and wildlife habitat (Figure 5b) and urban and industrial water use. Invasions of flood control reservoirs and flood drainage channels (Figure 5c) pose great risks to urban areas and agricultural lands and may decrease waterfront property values and economic viability of marinas. Dense infestations of the weeds during the summer growing season also impede water movement in canals at critical times for crop and wildlife needs. The plants can also cause hyperaccumulation of sediments that impacts water quality and the water capacity of natural and artificial channels (Dandelot et al. 2008).

Water primroses can affect the cost of food crop production. L. peploides is reported as a weed in rice fields in Argentina, Australia, California, Chile, and Columbia. Rice production in the Sacramento Valley of California is a successful $\$ 500$ million a year industry, due in part to effective efforts to manage aquatic weeds that otherwise decrease yields. Recently, L. hexapetala has invaded rice fields in California (Figure 5d); and the problem appears to be growing in areas where organically grown rice is produced, thus leading to increased production costs. 
Figure 5. Examples of economic and societal problems caused by invasive water primroses: a) flood control channels at Rohnert Park, California. High-density infestation of $L$. hexapetala is bright green, and it reduces flood retention capacity; b) Ludwigia peploides, irrigation canal San Joaquin Valley, CA; c) federal water supply canal pre-treatment of $L$. hexapetala, Colusa National Wildlife Refuge, $C A ; d) L$. hexapetala in rice, Butte County, CA; e) mosquito monitoring at Laguna de Santa Rosa, CA; f-g) costly mechanical removal at Kissimmee Lakes, FL; and $\mathrm{h}$ ) herbicide application in a water conveyance canal in CA.


The dense mats formed by noxious grouth of water primroses lead to an increased risk in mosquito-vectored diseases such as the West Nile Virus. The mats may provide a habitat and a safe refuge for mosquito larvae because they inhibit the effective application of larvicides for mosquito control. In the Laguna de Santa Rosa sub-basin of California's Russian River watershed, a record number of adult mosquitoes were trapped adjacent to the highest density patches of L. hexapetala (Figure 5e) at the time the West Nile Virus was first perceived as a public health threat, hence prompting a multi-million dollar control effort (Meisler 2009). 
Invasive water primrose also impacts public recreational opportunities. Dense stands reduce access to water and block waterways, interfering with human activities such as boating, fishing, hunting, and swimming. 


\section{Impacted Ecosystems}

Several aquatic ecosystems in the U.S. that are impacted by invasive water primroses represent unique resources from a global perspective. Select examples follow.

\section{Russian River Watershed, California}

The main channel of the Russian River is $177 \mathrm{~km}$ (110 mi) long, and the watershed drains $3,846 \mathrm{~km}^{-2}$ (1,485 square miles) to the Pacific Ocean in northern California. The river is the primary drinking water supply for Sonoma and Marin counties and provides irrigation water to support high value agricultural crops (primarily premium wine grapes). The Russian River is a federally managed river system with reservoir releases controlling river flows, especially throughout most of the summer and fall, to provide adequate flows for water supply, flood protection, and recreation and aquatic habitats. L. hexapetala has heavily invaded the river, which supports endangered coho salmon, threatened Chinook salmon, and steelhead trout (Figure 6). The Laguna de Santa Rosa Wetland Complex in the Russian River watershed is a RAMSAR designated wetland of international importance that includes seasonal and perennial freshwater wetlands such as creeks, ponds, marshes, vernal pools, swales, floodplains, riparian forest, and grasslands. The site has high conservation value as a habitat for fish, wildlife, and rare endemic plant and salamander species. The wetlands and waterways also provide irrigation, flood control, recreation, and aesthetic functions to the people of the Sonoma wine and dairy region. Changes to hydrology and increased nutrient loads from urban and agricultural wastewater are considered threats to this wetland, as is a major invasion of L. hexapetala. 
Figure 6. Spatial distribution of invasive Ludwigia hexapetala on the Healdsburg (patchy) and Asti (continuous bands) reaches of the Russian River, approximately $120 \mathrm{~km}$ (75 miles) north of San Francisco, California.
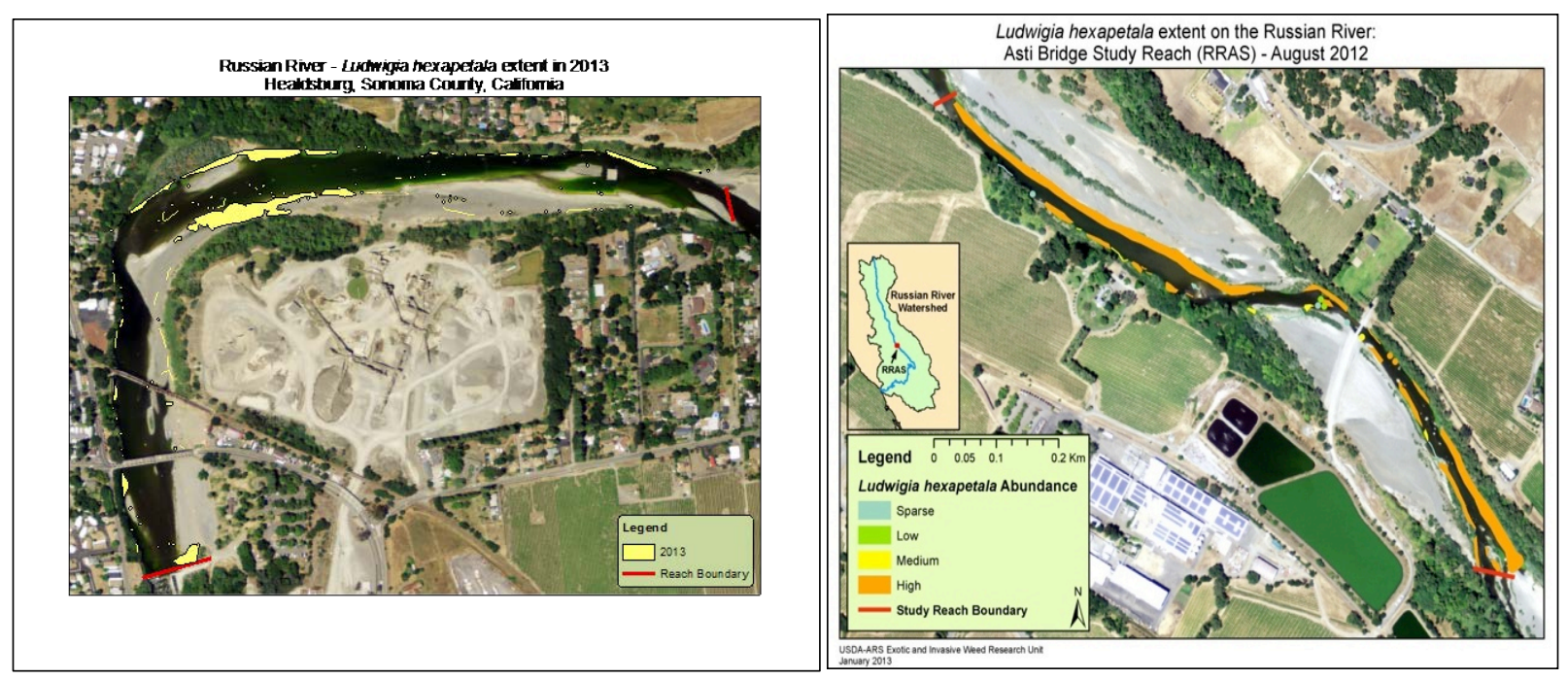

\section{Kissimmee Chain of Lakes, Florida}

The Kissimmee Chain of Lakes is the northern watershed and headwaters of Lake Okeechobee and the Everglades ecosystem. This unique ecosystem supports high biological diversity including endemic, temperate, and subtropical species and a widely shifting mosaic of habitats (USFWS 1999). The Kissimmee watershed includes numerous lakes, tributary streams, floodplains, and marshes distributed over 8,498 hectares (21,000 acres) in south Florida. The Kissimmee River historically meandered 166 km (103 miles) between Lake Kissimmee and Lake Okeechobee. Because of increased urbanization since the 1960s, the river has been extensively straightened and modified to regulate water levels for water supply and flood control purposes, and these changes are thought to contribute to persistent infestations of invasive, submersed, aquatic macrophytes (Allen and Tugend 2002). A large ecological restoration effort has been underway to restore historic flows and native plant, fish, and wildlife populations, and for this reason, a high degree of hydrologic connectivity is retained in the system. Recently, L. grandiflora invaded the Kissimmee Lakes. The reasons for this spread are poorly understood, but the hydrochorous dispersal of these weeds put the entire Everglades ecosystem at risk. Local environmental impacts of the L. grandiflora stands have been investigated along with other aquatic macrophytes. Bunch et al. (2010) evaluated DO concentrations in water within stands of five emergent macrophyte species in Lake Istokpoga, Florida. The most favorable or highest DO concentrations for aquatic life were found in cattail stands. Hypoxia in summer and fall was 48.6 times more likely in areas invaded by water 
primrose (unidentified Ludwigia spp.) where conditions were likely uninhabitable for many low DO-intolerant fish (Bunch et al. 2010). Low hydrologic exchange and high accumulation of organic sediments characterized environmental conditions in the dense floating islands of the water primrose. Although it merits further investigation, observations suggest patches of native grass and macrophyte stands within the lakes may play a facilitative role in the initial establishment and subsequent dominance of L. grandiflora.

\section{Santee Cooper Lakes, South Carolina}

Much of the flow of the Santee River, originating in the Blue Ridge Mountains, has long been diverted into Santee Cooper Lakes and the Cooper River. These lakes, connecting rivers, and associated tidal marshes provide hydropower, support agriculture and urban needs, and epitomize the South Carolina low country. Water primrose-willow, reported as Ludwigia uruguayensis by the South Carolina Department of Natural Resources (DNR) in 2008, is a management problem in the Santee Cooper lakes. Here, the plants grow to one meter ( three feet) tall in thickets along shorelines, where they have proven difficult to control due to extensive underground rhizomes (South Carolina DNR 2008). The water primrosewillow stands were initially restricted to the shoreline of Lake Marion, but when submersed Hydrilla verticillata infestations became quite dense in the lake, the Ludwigia sp. rooted in, and thrived on top of the buoyant Hydrilla beds (Davis 1997). This is apparently one way the primrosewillows establish free-floating mats and extend far from the shore in the lakes. The water primrose invasion has restricted boating and public access to waterways and shoreline areas, restricted water flow, degraded water quality, clogged water intakes, and affected power production.

\section{American Heritage River: St. Johns River, Florida}

One of the 14 rivers designated by the United States Environmental Protection Agency (EPA) to receive special attention towards natural resource and environmental protection and historic and cultural preservation is now in the early stages of invasion by L. hexapetala. The St. J ohns River is the longest river in the state of Florida. The river flows slowly north across a low gradient giving it notoriety as one of the laziest rivers in the world extending $500 \mathrm{~km}$ (310 miles) from broad marshes south of Cape Canaveral in Indian River County to the estuary at the Atlantic Ocean near J acksonville. The St. J ohns slowly drains a basin of 
$22,900 \mathrm{~km}^{-2}$ (8,840 square miles) and includes one of the major interior lake and wetland ecosystems of Florida. It is a blackwater system supported by its swamps and marshes receiving flow from both natural springs and urban storm water runoff. The river was named an American Heritage River in 1998, and in 2008 was included on a list of America's ten most endangered rivers. The earliest European reference to Florida is a map drawn by Alberto Cantino in 1502 that describes unique vegetation rafts in the St. J ohns River, prompting the early name Rio de las Almadias (River of Rafts) (Molander 2012). Today, the water primrose-willow impacts Lake Harney and Lake Monroe, two of the largest in a chain of lakes created by the river.

\section{American Heritage River: Willamette River, Oregon}

The Willamette River is also an EPA-designated American Heritage River that is impacted by invasion of L. hexapetala. From headwaters among the volcanoes of the Cascade Mountains, the cold water Willamette River flows north $301 \mathrm{~km}$ ( 187 miles) to join the Columbia River and discharge to the Pacific Ocean near Astoria, OR. The river was the terminus of the Oregon Trail, and since early pioneer days, it has been vital to the economy of the Willamette Valley and state of Oregon. Ludwigia hexapetala has been present in the Willamette watershed of Oregon since the 1940's, but did not become a problem until recently when it flooded historic gravel mining pits that are now operated as parks. Now, L. hexapetala patches occur along river shorelines of the mainstream of the Willamette River from Eugene downstream towards Portland. The river supports migrations of endangered salmonid fish. It is a spawning habitat for coho salmon, spring and fall run chinook (king) salmon, and steelhead and cutthroat trout. Protection and restoration of the river, wetlands, and floodplains are a high priority in Oregon, and local government agencies and environmental organizations have quickly responded to the threats imposed by water primrose. 


\section{Management Measures}

Resource managers must tailor effective management measures for the Ludwigia species to the particular species of concern, the environmental conditions of each invasion site, and the options and resources available. However, basic tenets of invasive aquatic weed management, coupled with knowledge of the ecology of the species, can be adapted to mitigate the problem at a range of sites. The first and most effective management strategy is prevention of new invasions. To be effective, prohibitions of sales and transport of aquatic Ludwigia species in nurseries, garden centers, and e-commerce sites must be implemented and coupled with a comprehensive, public targeted education program to reduce movement of plant material from existing to uninvaded sites. Restoration plans for invaded sites should include details of the distribution and abundance of water primrose species on a watershed scale. Thiébaut (2007a) suggests that manual removal is usually a practical alternative for rapid response to new or low-density invasions, but mechanical removal with carefully managed transport and disposal is necessary where plants are well established. Chemical treatment can replace or be integrated with manual or mechanical removal approaches, but in many areas herbicides have only been used as a last resort where water use, environmental conditions, and permits make them a viable option (Thiébaut 2007a). Since 2009, France has not allowed herbicide use for any applications in aquatic habitats due to perceived risks and indirect effects on reduced DO concentrations in water (Haury et al. 2010). However, managers in the UK and the U.S. have used herbicides with some success. Several aquatic-registered herbicide options are available in the U.S. varying by state and region. Some water resource managers still seek alternatives to herbicide use, particularly in public drinking water supplies and in sensitive fish and wildlife habitats. In an ecological and socio-economic assessment of potential environmental weed targets for classical biological control, L. grandiflora and L. peploides were recognized as a top priority for biological control in Europe (Gassmann et al. 2006, Sheppard et al. 2006). Interest for biological control is also high in the U.S. This approach could be especially useful as a component of integrated management in large lake systems and could reduce biomass and the extent of other costly actions. 
Regardless of the method used to remove or suppress biomass, it is important to recognize the species' recruitment potential from dormant seed banks that can generate new growth following management disturbance. Therefore, the timing of treatment or removal of biomass should occur before the flowering stage (Kelly and Maguire 2009) or during flowering, but before seed capsules expand and replenish sediment seed banks. For this reason, fall treatments are not advisable in areas with moist soil or drawdown zones where seed bank recruitment is most likely. Regardless of methodology, it is important to remove all plant material and use floating booms to contain fragments generated from management actions because water primroses can regenerate from small shoot fragments (Thiébaut 2007a) that quickly spread and establish throughout watersheds (Okada et al. 2009). Post-treatment monitoring for detection of reemergence is important. Resprouting capacity from rhizomes and/ or continued emergence from persistent seed banks suggest managers must plan for a long-term effort. 


\section{Select Management Case Studies}

\section{Peconic River, New York}

Current management efforts to control aquatic Ludwigia species are limited, and there is no consensus on best management practices. Management for water primroses has resulted in successes and failures, and there is still much to be learned about the best management practices for each. One of the best success stories comes from the Peconic River of Long Island, New York where L. peploides was first observed in 2003 (Stephenson 2008). By 2006, the Peconic Estuary Program formed a stakeholder partnership which included the Nature Conservancy, Freshwater Anglers of Long Island, Long Island Bassmasters, and others to eradicate the new invasion. The partnership also initiated an eradication and monitoring program that mobilized 438 volunteers who spent 2,360 hours hand-pulling 99 cubic meters (130 cubic yards) of L. peploides from the Peconic River (Peconic Estuary Program 2009). The group installed educational signage and developed a program to prevent introduction of non-native plants from aquaria and water gardens into natural lakes and rivers. By 2009, the group held "paddle the river" events to celebrate the successful containment of the weed, and vigilant monitoring and maintenance pulls continue to prevent resurgence.

\section{Laguna de Santa Rosa, Sonoma County, California}

A major invasion of L. hexapetala reached high levels of infestation in the Laguna de Santa Rosa tributary to the Russian River, associated floodplain, wetlands, and flood control channels before a local Ludwigia Task Force was formed to address the problem. Largely spurred by the potential threat of public health risk from mosquito-vectored West Nile Virus, a multi-million dollar effort was implemented over three years, using an integrated approach combining mechanical removal with glyphosate and trichlopyr herbicide applications. The short-term results achieved the objective of opening the waterways, but results were temporary and quite variable (Meisler 2009). Areas with the greatest water depths retained effects of management for two years, but regrowth to pre-project levels occurred in shallow wetland areas three to four years after treatment (Meisler 2009). Sustainable control was not achieved, but the nonprofit group who managed the effort learned important lessons 
that may improve future projects (Meisler 2009). For example, it is advisable to remove as much biomass as possible prior to use of herbicides to avoid extreme and unacceptable oxygen depletion levels that occur when sprayed biomass is left to decompose in the water column (Meisler 2009). Mechanical excavation of the flood control channels resulted in complete regrowth to pre-project or worse conditions within three years. Based on success of L. hexapetala control in canals elsewhere, this could have been avoided with minimal annual maintenance management. Management of a pernicious, perennial weed like L. hexapetala should not be approached as a short-term precursor to wetland restoration. The outcome of the project could have been improved by directly involving a collaborative team of experts in invasive aquatic weed ecology and management, and a commitment to long-term management of $L$. hexapetala as a component of comprehensive ecological restoration.

\section{Colusa West Lateral Canal, Sacramento Valley, California}

Concurrent with the Laguna de Santa Rosa project, a federal interagency team of biologists from the Sacramento National Wildlife Refuge Complex and plant ecologists from the United States Department of Agriculture, Agricultural Research Service (USDA-ARS) implemented an effort to achieve control of Ludwigia hexapetala in federal water project canals at Colusa National Wildlife refuge.

The team used an experimental framework to test and evaluate control efforts to learn about effects and implement adaptive management as needed. Integrated methods using mechanical removal with a long arm excavator and fork attachment, coupled with hydrologic manipulation and a glyphosate herbicide with aquatic-approved surfactant application with and without follow-up spot spraying were compared to overwater spraying of the herbicide mix with and without follow-up spot spraying. The goal of these treatments was to determine the most effective strategy while minimizing herbicide use. Both methods that included maintenance touch up herbicide treatments were successful, and without follow-up management, the treated areas returned to conditions comparable to experimental controls within 3 years. The integrated method was more costly in the short term, given mechanical removal costs, but preferable to chemical treatment alone that resulted in severe oxygen depletion in the water for extended periods. 


\section{Delta Ponds, City of Eugene, Willamette River Watershed, Oregon}

Invasive L. hexapetala invaded fish and wildlife habitats for western pond turtles and threatened juvenile Chinook salmon at restored gravel ponds, known as Delta Ponds, that have been reconnected to the Willamette River in Eugene, Oregon. In 2011 and 2012, the city initiated control efforts using contractors to manually pull low-density patches of the weed in aquatic areas upstream and downstream to successfully contain the worst infested area at the site, and to spot spray ( $2 \%$ glyphosate, $2 \%$ trichlopyr, and Agridex crop oil surfactant) L. hexapetala in terrestrial areas adjacent to the ponds (Figure 7). In 2013, the city of Eugene ramped up their efforts with a comprehensive Delta Ponds Invasive Ludwigia Control Project supported by the Oregon Weed Board, Oregon Department of Agriculture, and reviewed and advised by scientists with USDA-ARS, University of Oregon, and Oregon Department of Fish and Wildlife. The project continues the successful manual removal of low to moderate density patches and adds aquatic herbicide applications (glyphosate + crop oil surfactant) to the high infestation area of the site to minimize impacts to aquatic organisms (City of Eugene 2012). Photopoint monitoring and population mapping are used to assess plant community response to management in an adaptive framework (City of Eugene 2012). To date, three years after containment treatment and one year following herbicide treatment of the primary area, results of the effort have been very successful. 
Figure 7. Pretreatment conditions, hand removal and spot herbicide applications to invasive Ludwigia hexapetala at Delta Ponds Natural Area, Eugene, Oregon. Photo credit: Lauri Holts



\section{Current Research Activities}

Rapid expansion of L. hexapetala on the Russian River, and continued expansion in the Sacramento-San J oaquin Delta as well as numerous other sites in California, Oregon, and Washington have resource managers concerned. A similar rapid expansion of two Ludwigia polyploids has been observed in Florida on the St. J ohns River and Kissimmee Chain of Lakes. Continued expansion of invasive water primroses into key resources such as the Sacramento Delta, the Kissimmee River restoration projects, and acquired lands under the Comprehensive Everglades Restoration Program looks to be inevitable. Current management efforts are limited, partially due to taxonomic confusion, and there is no consensus on best management practices. There are few published studies regarding invasion, biology, and management of Ludwigia species present in the United States.

As pressure increases to manage a variety of Ludwigia polyploids, there is also a need to develop baseline biological and ecological data on populations present in the U.S. to optimize control efforts in a variety of lotic and lentic sites.

To address these concerns, the initial approach was to undertake biosystematics studies in the Pacific western states, update taxonomic treatments, and provide accurate information on the distribution of problematic Ludwigia taxa. Cytological and morphometric analyses of 80 populations from California to Washington, as well as molecular analyses of a subset of these populations have been completed. In addition, an updated taxonomic treatment of the genus Ludwigia in California was published (Hoch and Grewell 2012), and a taxonomic treatment for the Oregon Flora is nearly completed. Results of molecular analyses from populations in California detected very little genetic variation in L. hexapetala populations throughout California indicating the primary mode of reproduction is clonal (Okada et al. 2009). Final analyses of molecular samples from Ludwigia plant tissue collected in the South American native range are complete, and a manuscript is being finalized on this work to support research on potential biological control agents.

On-going studies on the biology and ecology of the Ludwigia species include research on seed bank recruitment under various hydrologic 
conditions, variation in decomposition of L. hexapetala with phenological stage and nutrient availability, plasticity of $\mathrm{L}$. hexapetala in response to hydrologic regimes, and physiological integration of L. hexapetala across experimental light gradients. Multi-year studies to evaluate integrated management methods for control of L. hexapetala in water supply canals are being completed. The frequency and timing of tillage and an integrated approach using sheep grazing to remove biomass prior to tillage in managed wetland habitat during the summer dry season at Colusa National Wildlife Refuge is under investigation.

New collaborative work is also underway by USDA-ARS and the U.S. Army Corps of Engineers (USACE) to expand the geographic and management focus of APCRP research efforts. The objectives of current studies in progress are to: 1) evaluate the response of diploid, hexaploid, and decaploid species of Ludwigia to environmental conditions such as available nutrient gradients; 2) improve understanding of dispersal and colonization dynamics of L. hexapetala; 3) evaluate the spatial dynamics of invasive L. hexapetala patches in the Russian River, California, and determine mechanism(s) and environmental factors driving their spatial expansion; and 4) determine seasonal patterns in production and allocation of biomass and carbohydrate storage reserves in L. hexapetala along water quality and depth gradients in the Russian River watershed. 


\title{
12 Identifying Research Priorities
}

\begin{abstract}
Multiple invasive Ludwigia species are a threat to native biological diversity and ecosystem function. Resource managers expect this to increase with greater global trade and projected climate change. Research is needed to improve understanding of the complexity of the biology and ecological invasion process of water primroses and to provide water resource managers with substantive recommendations for methods to prevent and prioritize management of these aquatic weeds. Life history strategies and responses to environmental conditions vary among water primrose species. Therefore, species-specific management approaches may be required, and prevention and control strategies should be customized to the specific phase of the local invasion.
\end{abstract}

1. Knowledge to Prevent and Contain Invasions. Prevention of introduction and invasive spread are considered the most cost-effective weed management strategies. Dispersal of Ludwigia species with water flow within watersheds is evident, but little is known about the provenance of Ludwigia introductions into new areas or among discrete watersheds. Potential pathways may include continued, intentional, and accidental introductions from horticultural or aquaria trade sources, movement by waterfowl and other vertebrates, and movement among watersheds by boat trailers. It is important to determine where invasive water primroses are coming from, evaluate methods to prevent introduction, and limit spread from existing invasion sites.

\section{Identify and Determine Distribution of Complicated Ludwigia}

Species. Accurate identification and understanding of the distribution of the species and potential hybrids is an essential first step in the development of prioritization and management strategies. Accurate identification of an invasive plant in its native and introduced range is also an important prerequisite for the success of any biological control project (Gaskin et al. 2013). Despitelong-standing taxonomic confusion surrounding aquatic Ludwigia species, recent ecological risk assessments point to the need for further study of the biosystematics of the genus (Nehring and Kolthoff 2011). Work is well underway to solvethis problem in the Pacific west states, but there is still considerable confusion regarding invasive taxa in Florida and elsewhere in eastern states. A comprehensive approach is needed that utilizes morphometric and cytogenetic evaluations 
of chromosome numbers to determine ploidy levels present at invasion sites, differentiate species, and improve taxonomic treatments. There is a need to evaluate molecular markers to assess local population structure, genetic diversity, and identify invasive genotypes. Phylogenetic and other molecular studies are also needed to compare local invasive genotypes with those in the native range to determine their degree of relatedness and to determine origin of locally invasive species.

\section{Improve Understanding of the Ecology of Dispersal and} Colonization Phases. Integrative studies that link demographic processes and key plant traits (e.g., propagule availability, survival, growth, reproduction, and fitness) with dispersal, colonization, and proliferation phases of spread of plants are needed (Ibáñez et al. 2014), as is the need to know how these key processes affect water primroses in a range of environmental conditions. Studies of colonization dynamics should include an evaluation of the competitive ability of Ludwigia spp. and competitive interactions with native or other desirable plant species in the context of historical watershed changes (DeGasperis and Motzkin 2007) to prevent conditions that would allow the invasive Ludwigia species to dominate native communities. Research to understand how these processes operate at individual, population, watershed, and regional scales are needed to guide management at multiple phases of ongoing invasions and across habitat types. This comprehensive approach can also identify vulnerable areas and inform predictions for different interacting management scenarios such as climate change, hydrologic change, and resource (light, nutrients, etc.) availability.

4. Mechanisms Driving Invasive Spread. There is a need to understand what triggers expansion of L. hexapetala as it moves from a patchy distribution following colonization to expansive colonies that cover large areas. To better understand patterns of distribution and abundanœ of $\mathrm{L}$. hexapetala, more detailed information is needed regardingyearly changes. Field observations suggest that not all invaded areas support continued, unabated patch colonization and expansion. Rather, some patches reduce their extent in some locations under some hydrologic conditions. Initial hypotheses for what drives these differences are factors such as hydrologic status (water depth relative to the rooting zone and temporal variability in water depth), as well as degree of disturbance during winter, when large floods can substantially rearrange river morphology. Improved understanding of what drives or limits expansion is important to water project managers who control timing and rates of flow for desired outcomes. 


\section{What Management Strategies Show Promise for Specific} Species and for Specific Habitat Types? Is Biological Control an Option? Published literature on the efficacy of herbicides to control water primroses is lacking, and anecdotal accounts often omit essential details for relevant, local manager decision-making. In addition, information is needed regarding the best treatment timing in different hydrological settings and for specific Ludwigia species. Likewise, information concerning non-target effects of management options is also desired. These evaluations should be assessed in an ecological restoration context. There are a growing number of managers who desire alternatives to chemical control where Ludwigia species have invaded rivers and lakes that serve as public drinking water supplies and/ or support to endangered fish species. Herbivorous insects associated with L. peploides have been identified in the southern U.S. (Harms and Grodowitz 2012). Lysathia and Altica water flea beetle species have been reported to feed on Ludwigia species and reduce biomass of invasive populations in Alabama (MoGregor et al. 1996), California (Carruthers et al. 2011), Texas (Campbell and Clark 1983), and Argentina (Cordo and DeLoach 1982). Further work is needed to determine if these insect populations can be augmented to reduce Ludwigia biomass in field settings at critical times in the life stage of Ludwigia. Recent studies on potential biological control agents for L. hexapetala and L. peploides have been completed in South America, and potential insect herbivores that merit further testing have been identified. Biosystematic studies are needed to clarify the origin and specific genotypes of invasive Ludwigia species in the U.S. Clarification will help support future host specificity testing of potential insect herbivores, particularly in the South Atlantic and Gulf states where multiple Ludwigia species exist and are thought to be native; however, molecular studies are needed for confirmation.

\section{Weed Management and Restoration Implications of Seed}

Banks. Ludwigia species maintain sediment seed banks. Recruitment from these seed banks can perpetuate infestations following management actions. Recruitment from seed banks are expected along rivers and in other aquatic systems with fluctuating water levels, since drawdown conditions promote recruitment. Seed banks even play a role in floating islands of vegetation where patches of sediment are less inundated than surrounding deeper water areas of marshes and lakes (Cherry and Gough 2006). Allocation to sexual reproduction is expected to vary with ploidy level. Studies are needed to assess germination requirements, ecology of the seed life stage of Ludwigia species with different ploidy levels, and 
seed bank dynamics under changing environmental conditions to support management techniques that deplete seed banks and improve restoration of desirable plant communities.

7. What Restoration Actions Can Reduce Negative Effects? In an assessment regarding the impact of invasive L. grandiflora and other macrophytes on hypoxia in Kissimmee Lakes, researchers suggested that selective removal of macrophytes and sediment to provide pathways for water movement inside dense stands could mitigate or increase aqueous DO concentrations and improve and expand habitat for fish and wildlife (Bunch et al. 2010). The merits of innovative solutions such as this should be experimentally tested and could be implemented as low-cost interim solutions while improvements to management methods for challenging sites are developed and improved. Herbicides were applied to L. grandiflora in floating islands within lakes. Following application of the herbicides, effective control of the target weed was observed; however, the native vegetation was also affected and recruitment of native species was limited. Studies are needed to evaluate treatment methods for $\mathrm{L}$. grandiflora, recruitment requirements of desirable plant species, and methods to restore open native grass communities in Florida lakes.

\section{How Invasive Will Ludwigia Species be with Climate Change,} and How Can We Prepare and Respond? Invasive Ludwigia species likely include different, sometimes locally adapted, species and populations that may differ in their ability to adjust (plasticity) to changing climate and other environmental conditions. Phenotypic plasticity and local adaptation are interacting factors that are generally not considered in models of species responses to climate change, but can greatly influence persistence and range expansion (Reed et al. 2011, Schwartz 2012). Simple climate matching models that rely on distribution of these species in their native range and project potential distribution outside of this range are not sufficient for Ludwigia species, since they have already invaded climate envelopes quite different from their area of origin. Research is needed to evaluate genetic adaptation vs. the degree of plasticity of regional populations to identify patterns of population differentiation, and how these factors affect the niche breadth of the invasive species. In turn, this information can provide resource managers with alternative environmental conditions and process management methods to control the spread of invasive Ludwigia weeds as it relates to climate change and new areas at risk for invasion. This research requires local population-level data on genetic and phenotypic variation, observational and experimental studies on local adaptation and phenotypic plasticity of multiple cytotypes 
of aquatic Ludwigia species across large spatial scales, and common garden experiments to evaluate traits that will be important for species persistence or demise. In general, herbivore-inflicted damage to plants can decrease plant fitness and can potentially decrease the ability of the plant species to adjust to environmental change (Gianoli et al. 2009). Using the framework described, experiments to test invasive Ludwigia traits and population responses to changing environments while under herbivore pressure could inform future biological control practices while remaining sustainable with climate change. 


\section{References}

Allen, M. S., and K. Tugend. 2002. Effects of a large-scale habitat enhancement project on habitat quality for age- 0 largemouth bass at Lake Kissimmee, Florida. In Black bass: ecology, conservation, and management, ed. D. P. Phillip,and M. S. Ridgeway, 265-276. Bethesda, MD: American Fisheries Society.

Bunch, A. J ., M. S. Allen, and D. C. Gwinn. 2010. Spatial and temporal hypoxia dynamics in dense emergent macrophytes in a Florida lake. Wetlands 30:429-435.

Campbell, J . M., and W. J . Clark. 1983. Observations on host selection by Lysathia ludoviciana (Chrysomelidae), a beetle with potential for biological-control of certain aquatic weeds. Texas J ournal of Science 35: 165- 167.

Carruthers, R.I., M.K. Franc, W.S. Gee, A.A. Cosse, B.J . Grewell, and J J . Beck. 2011. Volatile emissions from the flea beetle Altica litigata (Coleoptera: Chrysomelidae) associated with invasive Ludwigia hexapetala. Chemoecology 21: 253- 259.

Cherry, J .A. and L. Gough. 2006. Temporary floating island formation maintains wetland plant species richness: the role of the seed bank. Aquatic Botany 85:29-36.

City of Eugene, Oregon. 2012. Invasive Ludwigia Management Plan for the Delta Ponds Natural Area (Eugene, Oregon, 2013-2018). City of Eugene Department of Parks and Open Space Division, Eugene, Oregon. 14pp.

Cohen, M.F., C. Hare, J . Kozlowski, R.S. McCormick, L. Chen, L. Schneider, M. Parish, Z. Knight, T.A. Nelson, and B.J . Grewell. 2013. Wastewater polishing by a channelized macrophyte-dominated wetland and anaerobic digestion of the harvested phytomass. J ournal of Environmental Science and Health, Part A 48:1532-4117.

Cordo, H.A. and C.J . DeLoach. 1982. The Flea Beetle, Lysathia flavipes, That Attacks Ludwigia (Water Primrose) and Myriophyllum (Parrotfeather) in Argentina. The Coleopterists Bulletin, 36: 298-301.

Dandelot, S. 2004. Les Ludwigia spp. invasives du Sud de la France: historique, biosyste' matique, biologie et e' cologie. Universite' Paul CEZANNE, AixMarseille III, Marseille, p. 207.

Dandelot, S., R. Matheron, J .LePetit, R. Verlaque, and A. Caxaubon. 2005a. Temporal variation of physicochemical and microbiological parameters in three freshwater ecosystems (southeastern France) invaded by Ludwigia spp. Coptes Rendus Biologies 328:991-999.

Dandelot, S, R. Verlaque, A. Dutartre, and A. Cazaubon. 2005b. Ecological, dynamic, and taxonomic problems due to Ludwigia (Onagraceae) in France. Hydrobiologia 551:131- 136.

Dandelot, S., C. Robles, N. Pech, A. Cazaubon, and R. Verlaque. 2008. Allelopathic potential of two invasive Ludwigia spp. Aquatic Botany 88:311-316. 
Davis, W. 1997. The Effects of Hydrilla Infestation on Selected Wintering Waterfow: Santee Copper Lake System, South Carolina. M.S. Thesis, University of Western Kentucky. Masters Theses \& Specialist Projects. Paper 773. http://digitalcommons.wku.edu/theses/773.

DeGasperis, B.G. and G. Motzkin. 2007. Windows of opportunity: historical and ecological controls on Berberis thunbergii invasions. Ecology 88:3115-3125.

Ellmore, G.S. 1981. Root Dimorphism in Ludwigia peploides (Onagraceae) - Structure and Gas Content of Mature Roots. American J ournal of Botany 68(4):557-568

Ellstrand, N.C. and K.A. Schierenbeck. 2006. Hybridization as a stimulus for the evolution of invasiveness in plants? Euphytica 148: 35- 46.

EPPO. 2011a. Ludwigia grandiflora and L. peploides Onagraceae - water primroses. European and Mediterranean Plant Protection Organization EPPO Bulletin 41: 414-418.

EPPO. 2011b. European and Mediterranean Plant Protection Organization Report of a pest risk analysis for: Ludwigia grandiflora. Report 11-17142.

EPPO. 2011c. European and Mediterranean Plant Protection Organization Report of a pest risk analysis for: Ludwigia peploides. Report 11-17143.

Gaskin, J .F. and B.A. Schaal. 2002. Hybrid Tamarix widespread in US invasion and undetected in native Asian range. Proceedings of the Natural Academy of Sciences of the United States of America 99:11256-11259.

Gaskin, J.F., M. Schwarzländer, H.L. Hinz, L. Williams III, E. Gerber, B.G. Rector, and DY Zhang. 2013. Genetic identity and diversity of perennial pepperweed (Lepidium latifolium) in its native and invaded ranges. Invasive Plant Science and Management 6:268-280.

Gassmann, A., M.J.W. Cock, R. Shaw, and C.R. Evans. 2006. The potential for biological control of invasive alien aquatic weeds in Europe: a review. Hydrobiologia 570: 217- 222 .

Gianoli, E., I.M. Quezada, and L.H. Suárez. 2009. Leaf damage decreases fitness and constrains phenotypic plasticity to drought of a perennial herb. Acta Oecologia 35:752-757.

Guillaud, J . A. 1883. Flore de Bordeaux et du Sud Ouest. 1er volume: Phanérogames. G. Masson (eds), 217 pp.

Harms, N.E. and M.J . Grodowitz. 2012. Herbivorous insects associated with Ludwigia peploides (Onagraceae) in the southern United States. The Southwestern Naturalist 57:123-127.

Harper, R.M. 1904. Two hitherto confused species of Ludwigia. Torreya 4:161-164.

Haury, J , Matrat R, Lambert E, Anras L, Dutartre A, Bottner B, Gentil E, Gressette S, Loriot S, Martinant S, et al. 2010. Manuel de gestion des plantes exotiques envahissant les milieux aquatiques et les berges du bassin Loire-Bretagne. Fédération des conservatoires d'espaces naturels, Orléans, France. 
Hoch, P.C. and B.J . Grewell. 2012. Ludwigia. pp. 948-949 In Baldwin, B.G. (conv. ed.) The J epson Manual: Vascular Plants of California, Second Edition. University of California Press, Berkeley, California.

Hoch, P.C., W.L. Wagner and P.H. Raven. 2015. The correct name for a section of Ludwigia L. (Onagraceae). PhytoKeys 50:31-34.

Hollister, J.D. 2014. Polyploidy: adaptation to the genomic environment. New Phytologist doi: 10.1111/nph.12939

Hussner, A. 2009. Growth and photosynthesis of four invasive plant species in Europe. Weed Research 46:506-515.

Hussner, A. 2010. Growth response and root system development of the invasive Ludwigia grandiflora and Ludwigia peploides to nutrient availability and water level. Fundamentals in Applied Limnology, Archives in Hydrobiology 177:189196.

Ibáñez, I., J .M. Diez, L.P. Miller, J .D. Olden, C.J .B. Sorte, D.M. Blumenthal, B.A. Bradley, C.M. D’Antonio, J .S. Dukes, R.I. Early, E.D. Grosholz and J J . Lawler. 2014. Integrated assessment of biological invasions. Ecological Applications 24:25-37.

Jacono, C. Ludwigia hexapetala (Uruguayan primrose willow) in: New species for the Florida Exotic Pest Plant Council's 2013 list of invasive plant species. pp. 1-2 in: Florida Exotic Pest Plant Council, Wildland Weeds, Spring 2014, Supplement 1. 6 pgs.

Kelly, J . and C.M. Maguire. 2009. Water primrose (Ludwigia species) Exclusion strategy and invasive species action plan. Prepared for Northern Ireland Environment Agency and National Parks and Wildlife Service: Invasive Species Ireland. 15pp.

Lambert, E., A. Duarte, J . Coudreuse, and J . Haury. 2010. Relationships between the biomass production of invasive Ludwigia species and physical properties of habitats in France. Hydrobiologia 656:173-186.

Linnaeus, Carl to Christian Gottlieb Ludwig, $28 \mathrm{~J}$ uly 1737, sent from Hartecamp (Netherlands) to Leipzig (Germany), The Linnaean Correspondence, Linnaeus.c18.net, letter L0191. Royal Swedish Academy of Sciences, Uppsala University and the Linnean Society of London (accessed 20 October 2014, ).

Lodge, D.M., R.A. Stein, K.M Brown, A.P. Covich, C. Bronmark, J .E. Garvey, and S.P. Klosiewski. 1998. Predicting impact of freshwater exotic species on native biodiversity: challenges in spatial scaling. Australian J ournal of Ecology 23: 5367.

Maltchik, L., A.S. Rolon and C. Stenert. 2010. Aquatic macrophyte and macroinvertebrate diversity and conservation in wetlands of the Sinos River basin. Brazilian J ournal of Biology 70:1179-1184.

Martins, C. 1866. Sur les racines aérifères ou vessies natatoires des espèces aquatiques de genre J ussieae L. Memoires de l'Académie des Sciences de Montpellier, 353- 370. 
MoGregor, MA, D.R. Bayne, J.G. Steeger, E.C. Webber, and E. Reutebuch. 1996. The potential for biological control of water primrose (Ludwigia grandiflora) by the water primrose flea beetle (Lysathia ludoviciana) in the southeastern United States. J ournal of Aquatic Plant Management 34:74- 76.

McIntyre, S. and S.C.H. Barrett. 1985. A comparison of weed communities of rice in Australia and California. Proceedings of the Ecological Society of Australia 14:237-250).

Meisler, J . 2009. Lessons from Ludwigia control in Sonoma County. Cal-IPC News. 17: $4,5,12$.

Molander, A. 2012. The Horizons of Christopher Columbus: Using the Heavens to Map America. Lulu Press. Raleigh, North Carolina. ISBN 978-1-105-86335-6.

Munz, P.A. 1942. Studies in Onagraceae XII. A revision of the New World species of J ussiaea. Darwiniana 4:179-284, pls. 1-20.

Nehring, S. and D. Kolthoff. 2011. The invasive water primrose Ludwigia grandiflora (Michaux) Greuter \& Burdet (Spermatophyta: Onagraceae) in Germany: First record and ecological risk assessment. Aquatic Invasions 6:83-89.

Nesom, G.L. and J.T. Kartesz. 2000. Observations on the Ludwigia uruguayensis complex (Onagraceae) in the United States. Castanea 65:123-125.

Okada M, B.J . Grewell, and M. J asieniuk. 2009. Clonal spread of invasive Ludwigia hexapetala and L. grandiflora in freshwater wetlands of California. Aquatic Botany 91: 123- 129.

Pandit, M.K., S.M. White, and M.J .O. Pocock. 2014. The contrasting effects of genome size, chromosome number and ploidy level on plant invasiveness: a global analysis. New Phytologist 203:697-703.

Peconic Estuary Program. 2009. Ludwigia peploides in the Peconic River. Peconic Estuary Program, Yaphank, New York. http://peconice.ipower.com/pdf/SCPE_v2.pdf

Pivari, M.O., V.J . Pott, and A. Pott. 2008. Macrófitas aquáticas de ilhas flutuantes (baceiros) nas sub-regiões do Abobral e Miranda, Pantanal. Brasilica 22:563-571.

Ramírez, C., J. San Martín, C. San Martín, and D. Contreras. 1991. The chemical composition and energetic content of the biomass of weeds in rice fields in central Chile. Turrialba 41:551-563.

Reed, T.E., D.E. Schindler, and R.S. Wapales. 2011. Interacting effects of phenotypic plasticity and evolution on population persistence in a changing climate. Conservation Biology 25:56-63.

Reichard, S.H. and P. White. 2001. Horticulture as a pathway of invasive plant introductions in the United States. BioScience 51:103-113.

Rejmánková, E. 1992. Ecology of creeping macrophytes with special reference to Ludwigia peploides (H.B.K.) Raven. Aquatic Botany 43:283-299. 
Rolon, A.S., T. Lacerda, L. Maltchik, and D.L. Guadagnin. 2008. Influence of area, habitat and water chemistry on richness and composition of macrophyte assemblages in southern Brazilian wetlands. J ournal of Vegetation Science 19: 221- 228.

Ruaux, B., S. Greulich, J . Haury, and J.P. Berton J P. 2009. Sexual reproduction of two invasive Ludwigia (Onagraceae) on the middle Loire River, France. Aquatic Botany 90: 143- 148, doi:10.1016/j.aquabot.2008.08.003

Sabattini, R.A. and V.H. Lallana. 2007. Aquatic macrophytes. In: M.H. Iriondo, J .C. Paggi, M.J . Parma (eds.) The Middle Parana River: Limnology of a Subtropical Wetland. Springer-Verlag Berlin Heidelberg. Pp. 205-226.

Sabattini, R.A., V.H. Lallana, S. Sione, F. Dorsch, and C. Mathern. 1998. Aquatic and wetland plants inventory of rice fields of Entre Rios (Argentina). Pp. 115-117 in: Monterio, A., Vasconcelos, T. and Catarino, L. (eds.) Management and ecology of aquatic Plants. Proceedings of the $10^{\text {th }}$ EWRS International Symposium on Aquatic Weeds, Lisbon, Portugal, 21-25 September 1998.

Schwartz, M.W. 2012. Using niche models with climate projections to inform conservation management decisions. Biological Conservation 155:149-156.

Schultz, R. and E. Dibble. 2012. Effects of invasive macrophytes on freshwater fish and macroinvertebrate communities: The role of invasive plant traits. Hydrobiologia 684:1- 14 .

Sheppard, A.W., R.H. Shaw, and R. Sforza. 2006. Top 20 environmental weeds for classical biological control in Europe: a review of opportunities, regulations and other barriers to adoption. Weed Research 46: 93- 117.

South Carolina Department of Natural Resources. 2008. South Carolina aquatic invasive species management plan. Columbia, South Carolina.

Stephenson, L. 2008. We came, we pulled and we conquered! PEP Talk. Newsletter of the Peconic Estuary Program 4(3):1,4. http://www.peconicestuary.org/newsletters/October2008.pdf

Stiers I., N. Crohain, G. J osens, and L. Triest. 2009. Impact of aquatic invasive species on native plant and benthic invertebrate assemblages in Belgian ponds. Reports of Finnish Environment Institute 15: 120- 121.

Stiers, I., N. Crohain, and G. J osens. 2011. Impact of three aquatic invasive species on native plants and macroinvertebrates in temperate ponds. Biological Invasions 13:2715-2726.

te Beest, M., J .J . Le Roux, D.M. Richardson, A.K. Brysting, J . Suda, M. Kubešová and P. Pyšek. 2012. The more the better? The role of polyploidy in facilitating plant invasions. Annals of Botany 109:19-45.

Thiébaut, G. 2007a. Non-indigenous aquatic and semiaquatic plant species in France. In: Gherardi F (ed) Biological invaders in inland waters: profiles, distribution and threats. Springer, Dordrecht, pp 209- 229. 
Thiébaut, G. 2007b. Invasion success of non-indigenous aquatic and semi-aquatic plants in their native and introduced ranges. A comparison between their invasiveness in North America and France. Biological Invasions 9:1-12.

Thiébaut, G. and A. Dutartre. 2009. Management of invasive aquatic plants in France. In: Aquatic Ecosystem Research Trends, Nairne GH (ed.). Nova Science Publishers: New York; 25- 46.

Thouvenot, L., J . Haury, and G. Thiébaut. 2013a. A success story: water primroses, aquatic plant pests. Aquatic Conservation: Marine and Freshwater Ecosystems 23:790-803.

Thouvenot, L., J . Haury, and G. Thiébaut. 2013b. Seasonal plasticity of Ludwigia grandiflora under light and water depth gradients: an outdoor mesocosm experiment. Flora 208:430-437.

Thouvenot, L., C. Puech, L. Martinez, J . Haury, and Thiébaut. 2013c. Strategies of the invasive macrophyte Ludwigia grandiflora in its introduced range: competition, facilitation or coexistence with native and exotic species? Aquatic Botany 107:816.

U.S. Fish and Wildlife Service (USFWS). 1999. South Florida multi-species recovery plan. Atlanta, GA. 2172 pp.

Vitousek, P.M., C.M. D’Antonio, L.L. Loope, M. Rejmanek, and R. Westbrooks. 1997. Introduced species: a significant component of human-caused global change. New Zealand J ournal of Ecology 21: 1- 16.

Wagner, W.L. and P.C. Hoch. 2005. Onagraceae, The Evening Primrose Family website. Smithsonian Institution. http://botany.si.edu/onagraceae/index.cfm [9/2014 access]

Wagner, W.L., P.C. Hoch and P.H. Raven. 2007. Revised classification of the Onagraceae. Systematic Botany Monographs 83: 1-240.

Washington Department of Ecology. May 2000. Water Primrose (Ludwigia hexapetala) - A Noxious Aquatic Weed in Washington. Available: http://www.ecy.wa.gov/programs/wq/plants/weeds/water_primrose.html

Zardini, E.M., H. Gu and P.H. Raven. 1991a. On the separation of two species within the Ludwigia uruguayensis Complex (Onagraceae). Systematic Botany 16:242-244.

Zardini, E.M., C-I. Peng and P.C. Hoch. 1991b. Chromosome numbers in Ludwigia sect. Oligospermum and sect. Oocarpon (Onagraceae). Taxon 40:221-230. 




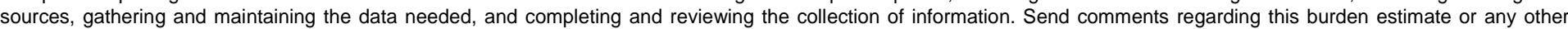

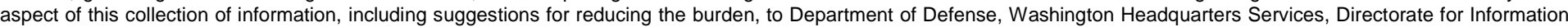

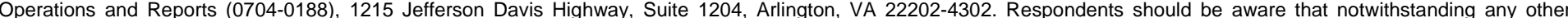
provision of law, no person shall be subject to any penalty for failing to comply with a collection of information if it does not display a currently valid OMB control number. PLEASE DO NOT RETURN YOUR FORM TO THE ABOVE ADDRESS.

\begin{tabular}{l|l|l}
\hline $\begin{array}{l}\text { 1. REPORT DATE } \\
\text { February } 2016\end{array}$ & $\begin{array}{l}\text { 2. REPORT TYPE } \\
\text { TR }\end{array}$ & 3. DATES COVERED July 2013 to \\
September 2014
\end{tabular}

\section{TITLE AND SUBTITLE}

Establishing Research and Management Priorities for Invasive Water Primroses (Ludwigia spp.)

5a. CONTRACT NUMBER

5b. GRANT NUMBER

5c. PROGRAM ELEMENT NUMBER

5d. PROJECT NUMBER

\section{5e. TASK NUMBER}

5f. WORK UNIT NUMBER

\section{PERFORMING ORGANIZATION NAME(S) AND ADDRESS(ES)}

USDA-Agricultural Research Service

University of California-Davis, Dept. of Plant Sciences MS-4. One Shields Avenue, Davis, CA 95616

US Army Engineer Research and Development Center

Environmental Laboratory

9. SPONSORING/MONITORING AGENCY NAME(S) AND ADDRESS(ES)

US Army Engineer Research and Development Center, Environmental Laboratory, 3909 Halls Ferry Road, Vicksburg, MS 39180

\section{PERFORMING ORGANIZATION REPORT NUMBER}

ERDC/EL TR-16-2

10. SPONSOR/MONITOR'S ACRONYM(S)

11. SPONSOR/MONITOR'S REPORT NUMBER(S)

\section{DISTRIBUTIONIAVAILABILITY STATEMENT}

Approved for public release; distribution is unlimited.

\section{SUPPLEMENTARY NOTES}

\section{ABSTRACT}

Creeping water primroses and water primrose-willows are among the most aggressive aquatic invasive plant invaders in the world. These aquatic Ludwigia species can impart severe ecological, economic, and human health impacts in aquatic ecosystems and threaten critical ecosystem functions. We expect these impacts to increase with greater global trade and projected climate change. This technical report presents an overview of the biology and ecology of these invasive plant species, along with select management case studies and research efforts. While the need for management approaches has become an important topic, little is known about the distribution of Ludwigia species and how they respond to varying environmental conditions in the U.S. Life history strategies and responses to environmental conditions vary among water primrose species. Therefore, species-specific management approaches may be required, and prevention and control strategies should be customized to the specific phase of the local invasion. This information is important for predicting further spread. Likewise, it is the foundation for risk assessments and effective management. This technical report proposes research priorities to improve understanding of the complexity of the biology and ecological invasion process of water primroses, and it provides resource managers with substantive recommendations for how to prevent and prioritize management of these aquatic weeds.

\section{SUBJECT TERMS}

Invasive aquatic plants, Aquatic Plant Control, Aquatic Plant Management, Invasive plant biology and ecology, water primrose management, aquatic herbicide, biological control

16. SECURITY CLASSIFICATION OF:

\begin{tabular}{ll|ll} 
a. REPORT & b. ABSTRACT & c.THIS PAGE
\end{tabular}

U

U

U
17. LIMITATION OF ABSTRACT

UU
18. NUMBER OF PAGES

53 19a. NAME OF RESPONSIBLE PERSON Michael D. Netherland

19b. TELEPHONE NUMBER (Include area code) 352-392-0335 